\title{
TNFa affects CREB-mediated neuroprotective signaling pathways of synaptic plasticity in neurons as revealed by proteomics and phospho-proteomics
}

\author{
Pia Jensen ${ }^{1}$, Christa L. Myhre ${ }^{2}$, Pernille S. Lassen ${ }^{1}$, Athanasios Metaxas ${ }^{2}$, Asif M. \\ Khan ${ }^{2,5}$, Kate L. Lambertsen ${ }^{2,3,4}$, Alicia A. Babcock ${ }^{2}$, Bente Finsen ${ }^{2,4, *}$, Martin R. \\ Larsen $^{1, *}$ and Stefan J. Kempf ${ }^{1}$ \\ ${ }^{1}$ Department of Biochemistry and Molecular Biology, University of Southern Denmark, Odense, Denmark \\ ${ }^{2}$ Neurobiology Research, Institute of Molecular Medicine, University of Southern Denmark, Odense, Denmark \\ ${ }^{3}$ Department of Neurology, Odense University Hospital, Odense, Denmark \\ ${ }^{4}$ BRIDGE, Brain Research-Inter-Disciplinary Guided Excellence, Department of Clinical Research, University of Southern \\ Denmark, Odense, Denmark \\ ${ }^{5}$ Current address: Department of Biochemistry and Molecular Biology, University of Southern Denmark, Odense, Denmark \\ "These authors are equally contributed to these work
}

Correspondence to: Stefan J. Kempf, email: stefank@bmb.sdu.dk

Keywords: $m T O R$, neuroinflammation, alzheimer's disease, post translational modification, LPS

Received: March 21, $2017 \quad$ Accepted: July 11, $2017 \quad$ Published: July 21, 2017

Copyright: Jensen et al. This is an open-access article distributed under the terms of the Creative Commons Attribution License 3.0 (CC BY 3.0), which permits unrestricted use, distribution, and reproduction in any medium, provided the original author and source are credited.

\section{ABSTRACT}

Neuroinflammation is a hallmark of Alzheimer's disease and TNFa as the main inducer of neuroinflammation has neurodegenerative but also pro-regenerative properties, however, the dose-dependent molecular changes on signaling pathway level are not fully understood. We performed quantitative proteomics and phosphoproteomics to target this point.

In HT22 cells, we found that TNFa reduced mitochondrial signaling and inhibited mTOR protein translation signaling but also led to induction of neuroprotective MAPKCREB signaling. Stimulation of human neurons with TNFa revealed similar cellular mechanisms. Moreover, a number of synaptic plasticity-associated genes were altered in their expression profile including CREB.

SiRNA-mediated knockdown of CREB in human neurons prior to TNFa stimulation led to a reduced number of protein/phospho-protein hits compared to siRNA-mediated knockdown of CREB or TNFa stimulation alone and countermeasured the reduced CREB signaling. In vivo data of TNFa knockout mice showed that learning ability did not depend on TNFa per se but that TNFa was essential for preserving the learning ability after episodes of lipopolysaccharide-induced neuroinflammation. This may be based on modulation of CREB/CREB signaling as revealed by the in vitro / in vivo data.

Our data show that several molecular targets and signaling pathways induced by TNFa in neurons resemble those seen in Alzheimer's disease pathology.

\section{INTRODUCTION}

Elevated levels of the cytokine tumor necrosis factor- $\alpha$ $(\mathrm{TNF} \alpha)$ have been associated with neurodegenerative diseases such as Alzheimer's disease (AD) where increased levels of TNF $\alpha$ has been found in brains and cerebrospinal fluid of AD patients [1]. Systemic inflammation leading to increased TNF $\alpha$ is associated with disease progression/ cognitive decline in $\mathrm{AD}$ patients [2], and systemic challenge, such as administration of lipopolysaccharide (LPS), can provoke waves of TNF $\alpha$ expression in the rodent brain [3]. The signaling events triggered by TNF $\alpha$ that culminate into neurodegeneration are still unclear but may include an imbalance in molecular pathways where TNF $\alpha$ contributes to neuronal injury but also exerts protective effects [4]. Accumulating knowledge from trials investigating anti-inflammatory drugs as candidates to prevent or slow progression of neurodegenerative diseases 
have also revealed controversial results [5]. Similarly, $\mathrm{TNF} \alpha$ inhibitors have been used to eliminate TNF $\alpha$ in order to prohibit cell death in an AD phase 2 trial [6] but only with marginal effects. These observations may rely on the reductions of the neuroprotective properties of cytokines and suggests that a better understanding of the pathway dynamics is mandatory.

TNF $\alpha$ acts on the two receptors, TNFR 1 and TNFR2, which are generally hold to have opposing effects e.g. on cell survival [7]. TNFR1, which contains a death domain, mainly shows neurodegeneration signaling although it also reveals neuroprotection in vivo [8] while TNFR2, which is without a death domain, is neuroprotective [9]. Importantly, it has been shown that local increase of TNF $\alpha$ in the hippocampal dentate gyrus activates astrocytic TNFR1, which in turn triggers an astrocyte-neuron signaling cascade that results in the persistent functional decline of hippocampal excitatory synapses [10]. In this context, $\mathrm{TNF} \alpha$ exerts additional control of hippocampal synapses via $\alpha$-amino-3-hydroxy5-methyl-4-isoxazolepropionic acid (AMPA) [11] and gamma-aminobutyric acid (GABA) [12] receptor trafficking emerging as a key physiological regulator of hippocampal synaptic plasticity and modulator of neural injury [13]. Notably, it has been shown that TNFR1-triggered signaling might mediate mitochondrial function and induces apoptosis in neurons in vitro [13]. Neuroprotection via TNFR2 signaling may involve upregulation of BDNF protein, decrease in glutaminase levels and modulation of N-methyl-D-aspartate (NMDA) receptors [14]. Despite the fact that each receptor type mediates distinct cellular responses, there are also evidences of considerable overlap of their signaling capabilities in mediating biological outcomes [15-17]. Noteworthy, TNFR1-mediated apoptosis occurs during high TNF $\alpha$ levels whereas small amounts of TNF $\alpha$ in the low $\mathrm{ng} / \mathrm{ml}$ range activate the TNFR2-mediated signaling cascade $[7,18]$.

We believe that the underlying molecular mechanisms and cellular responses of TNF $\alpha$ need to be investigated in a dose-dependent and global manner in order to better understand $\mathrm{AD}$ etiology and other neurological diseases where TNF $\alpha$ plays a pivotal role in triggering neuroinflammation and affecting synaptic plasticity.

\section{RESULTS}

\section{Dose-dependent inhibition of cell proliferation and induction of apoptosis by TNF $\alpha$ in HT22 cells}

To investigate dose-dependency of TNF $\alpha$ on HT22 neuronal cells, we incubated 2500 cells/well and 5000 cells/well with increasing TNF $\alpha$ concentrations from $0.1 \mathrm{ng} / \mathrm{ml}$ to $100.0 \mathrm{ng} / \mathrm{ml}$ for 24 hours. We observed a dose-dependent inhibition of cell proliferation starting at $1.0 \mathrm{ng} / \mathrm{ml}$ whereas cell death was induced already at $0.1 \mathrm{ng} / \mathrm{ml} \mathrm{TNF} \alpha$ (Figure 1A and 1B). Based on these observations, we performed further experiments with a maximal dose of $10.0 \mathrm{ng} / \mathrm{ml}$ and excluded $100.0 \mathrm{ng} / \mathrm{ml}$ as it may over-induce apoptosis signaling (Figure 1B).

\section{Global mass spectrometry-based protein and phospho-protein quantification reveals dose- dependent impairment in energy metabolism and synaptic plasticity in HT22 cells}

To elucidate the molecular mechanism behind low dose $(0.1$ and $1.0 \mathrm{ng} / \mathrm{ml})$ and moderate $\mathrm{TNF} \alpha$ concentrations $(10.0 \mathrm{ng} / \mathrm{ml})$, we performed a global quantitative proteome and phospho-proteome analysis after 30 minutes and 24 hours of TNFa stimulation in HT22 cells. We noted that the number of significantly changed proteins $(0.1 \mathrm{ng} / \mathrm{ml} / 1 \mathrm{ng} / \mathrm{ml}: 0 / 1$ (30 minutes) and $0 / 4$ (24 hours)) and phospho-proteins $(0.1 \mathrm{ng} / \mathrm{ml} /$ $1 \mathrm{ng} / \mathrm{ml}: 0 / 0$ (30 minutes) and 1/0 (24 hours)) induced by the two lower TNF $\alpha$ concentrations are scarce compared with the high numbers of alterations seen at $10.0 \mathrm{ng} / \mathrm{ml}$ dose (proteins: 106 (30 minutes) and 778 (24 hours); phospho-proteins: 1 (30 minutes) and 287 (24 hours)) (Figure 2A, Supplementary Table 5). Supplementary Tables $1-4$ show the identifiable and quantifiable protein and phospho-protein hits.

Bioinformatics analysis of signaling pathways using IPA software showed that energy production (Glycolysis, Gluconeogenesis, Oxidative Phosphorylation and Mitochondrial Dysfunction) and cell proliferative / proteintranslational signaling pathways (Eif2 Signaling, mTOR Signaling, Regulation of eiF4 and p70S6K Signaling) as well as synaptic plasticity-associated signaling (Signaling by Rho Family GTPases and Remodeling of Adherens Junctions) were not changed at the 30 minutes time point either at protein or phospho-protein level (Figure 2A). However, we noted that the affected signaling pathways were all significantly modulated by a TNF $\alpha$ dose of $10 \mathrm{ng} /$ $\mathrm{ml}$ after 24 hours of incubation on the protein level whereas only EIF2 Signaling, mTOR Signaling and Regulation of eif4 and p70S6K Signaling correlated in addition on phospho-level to the pathways changes seen on protein level (Figure 2A). Notably, we observed a significant inhibition of $\mathrm{mTOR}$ at $10.0 \mathrm{ng} / \mathrm{ml} \mathrm{TNF} \alpha$ stimulation for 24 hours (Figure 2A and 2B) based on our deregulated proteins (Supplementary Table 5)

\section{TNF $\alpha$-stimulation of HT22 cells leads to reduction in mitochondrial protein expression and activation of synaptic plasticity-associated CREB signaling}

To validate the TNF $\alpha$-induced changes in signaling pathways, we performed immunoblotting of key 
proteins associated within these signaling pathways. The mitochondrial proteins Atp5a (Complex V) and Uqcrc2 (Complex III) but not Sdhb (Complex II) or Ndufb8 (Complex I) were significantly reduced in their expression levels after 24 hours of TNF $\alpha$ incubation only at a dose of 1.0 and $10.0 \mathrm{ng} / \mathrm{ml}$ (Figure $3 \mathrm{~A}$ and $3 \mathrm{~B}$ ) correlating well with the bioinformatics-based deregulated signaling pathways of Oxidative Phosphorylation and Mitochondrial Dysfunction at these doses (Figure 2A). Proteomics revealed an increased protein expression of Mtco2 and Cox3 (Complex IV) at $1.0 \mathrm{ng} / \mathrm{ml}$ as well as increased protein expression of Atp51 (Complex V) and a number of abundance alterations of Complex I proteins (decrease in Ndufs7, Ndufs8, Ndufc2; increase in Ndufs2) at $10.0 \mathrm{ng} / \mathrm{ml} 24$ hours TNF $\alpha$ stimulation for 24 hours (Supplementary Table 5). Sdhb (Complex II) was significantly increased in the proteomics data set (Supplementary Table 5) whereas immunoblotting showed no change (Figure $3 \mathrm{~A}$ and $3 \mathrm{~B}$ ).

Next, we quantified CREB and p-CREB levels as they are essential synaptic plasticity regulators within neurons and modulate Rho signaling [19] which we noted
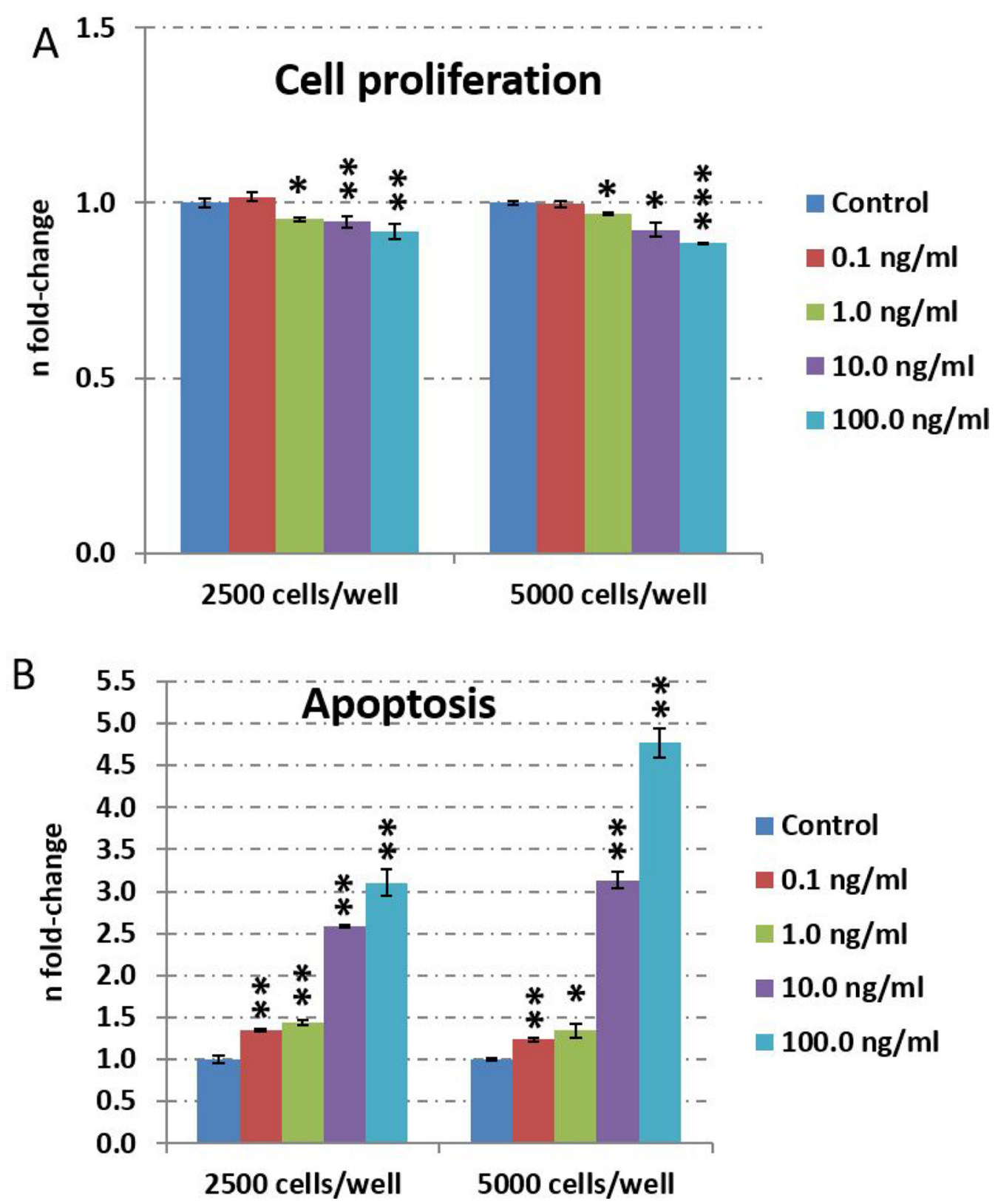

Figure 1: TNF $\alpha$ dose-dependent evaluation of cell proliferation and apoptosis in HT22 cells. Cell proliferation (A) and apoptosis (B) was quantified by CellTiter-Glo ${ }^{\circledR}$ Cell viability assay and Caspase-Glo ${ }^{\circledR}$ 3/7 assay, respectively. Cells were cultured with a density of 2500 or 5000 per well in 96-well plates. The cells were stimulated with $0.1,1,10$ or $100 \mathrm{ng} / \mathrm{ml} \mathrm{TNF} \alpha$ for 24 hours and untreated cells served as control. The figures show the fold-change and the standard error of the mean of five biological replicates per group. Statistical analysis was performed with unpaired Student's test; ${ }^{*} p<0.05 ; * p<0.01 ; * * p<0.001$. 
to be affected in HT22 neurons by TNF $\alpha$ (Figure 2A). We observed that $\mathrm{p}$-CREB but not CREB levels were significantly increased at a dose of $10.0 \mathrm{ng} / \mathrm{ml} \mathrm{TNF} \alpha$ whereas their pattern was not changed at lower doses (Figure 3C and 3D).

To validate our observations in cell proliferative / protein translational signaling pathways, we quantified MAPK (Erk1/2), p-MAPK (p-Erk1/2) as well as total phospho-proteins with PKA and PKC phosphorylation consensus motif as surrogates for these pathways as mTOR and MAPK pathways converge on eIF4 signaling [20]. We only noted an increase in MAPK but not p-MAPK levels at a dose of $10.0 \mathrm{ng} / \mathrm{ml} \mathrm{TNF} \alpha$ (Figure $3 \mathrm{C}$ and 3D) that was accompanied by a decrease in total PKA upstream of MAPK signaling but not PKC activity as revealed by phospho-PKA/-PKC Substrate Antibody immunoblotting (Figure $3 \mathrm{E}$ and $3 \mathrm{~F}$ ).

\section{Increased cell proliferation potential by low-dose TNF $\alpha$ stimulation in human neurons}

Next, we changed our in vitro model to human embryonic stem cell-derived neurons to elucidate the molecular neuronal mechanism of TNF $\alpha$ closer to human neuronal physiology. By using immunofluorescence, we show that the differentiation process resulted in a neuronal population ( $\beta$-tub III staining) with very few Ki67positive proliferating NSCs and a substantial number of GABAergic neurons (Supplementary Figure 1). Moreover, very few GFAP-positive astrocytes were observed in the cultures (not shown).

We also investigated the dose-dependency of TNF $\alpha$ and its influence on cell death and cell proliferation. We noted that apoptosis is significantly induced by 100.0 $\mathrm{ng} / \mathrm{ml} \mathrm{TNF} \alpha$ stimulation over 24 hours but not at lower doses (Figure 4B) whereas cell proliferation was increased at $0.1 \mathrm{ng} / \mathrm{ml}, 1.0 \mathrm{ng} / \mathrm{ml}$ and $10.0 \mathrm{ng} / \mathrm{ml}$ dose but not at $100.0 \mathrm{ng} / \mathrm{ml}$ dose (Figure 4A) in human neurons.

\section{TNF $\alpha$ influences signaling pathways of mTOR, protein synthesis and mitochondrial function in human neurons}

Global mass spectrometry-based proteomics and phospho-proteomics of $1.0 \mathrm{ng} / \mathrm{ml}$ TNF $\alpha$ stimulation of human neurons over 24 hours showed a deregulation of 20 proteins and 23 phospho-proteins (Figure 5A, Supplementary Table 10). Supplementary Tables 6-9 show the identifiable and quantifiable proteins and phospho-proteins. Bioinformatics analysis of signaling
A

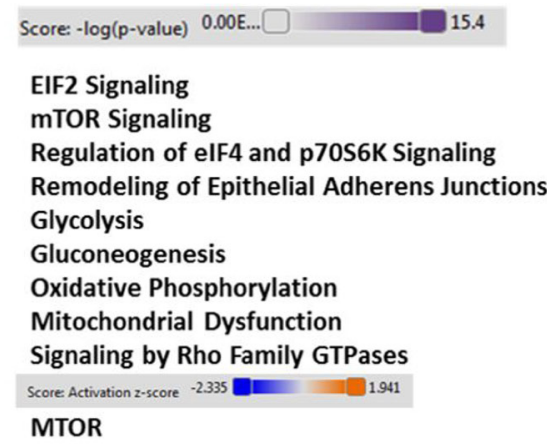

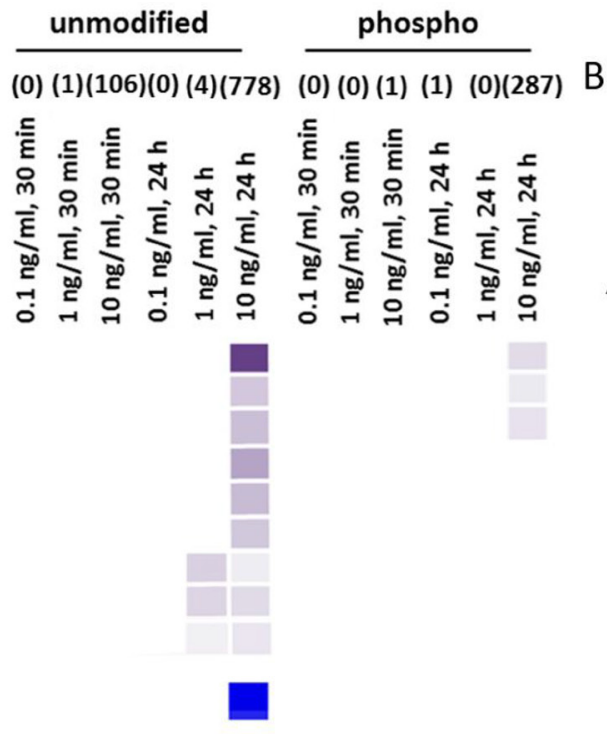

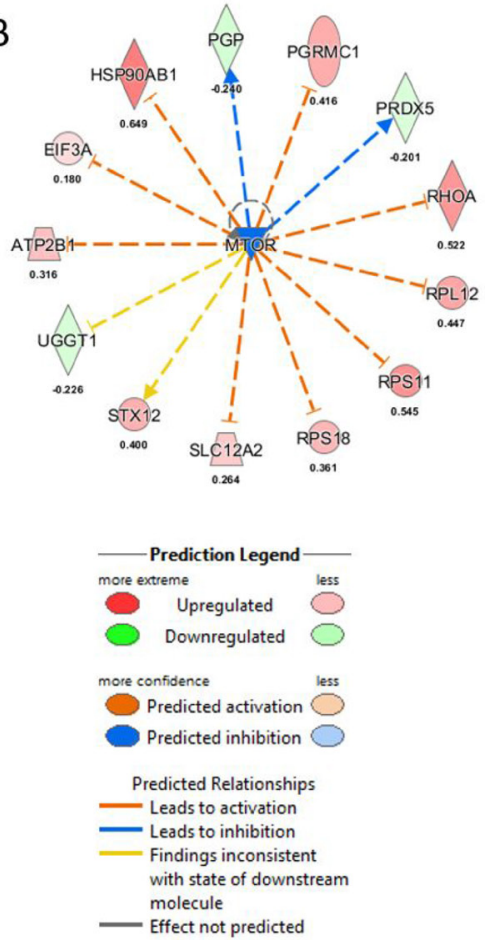

Figure 2: Analysis of signaling pathways from proteomics and phospho-proteomics experiments in HT22 cells. Altered $\mathrm{TNF} \alpha$ dose-dependent signaling pathways in HT22 cells on the proteome and phospho-proteome using Ingenuity Pathway Analysis software are shown in panel (A) High colour intensity represents high significance ( $p$ value) of the pathway. All coloured boxes have a $p$ value $\leq 0.05$; white boxes have a $p$ value $\geq 0.05$ and are not significantly changed; $n=3$ in each group. Panel (A and $\mathbf{B}$ ) show the upstream regulator analysis from IPA software (z-score $>2.0$ : predicted significant activation of node; $z$-score $<2.0$ : predicted significant inhibition of node) were grouped and visualized from proteins (unmodified) of $10 \mathrm{ng} / \mathrm{ml} \mathrm{TNF} \alpha$ stimulation over 24 hours. There was no significant change in the other groups. 
pathways using IPA software showed changes in mitochondrial function (Oxidative Phosphorylation, Mitochondrial Dysfunction) and cell proliferative/proteintranslational signaling pathways (Eif2 Signaling, mTOR Signaling, Regulation of eiF4 and p70S6K Signaling) (Figure 5A).

Altered mitochondrial function was validated by a MitoMP assay but did not show any dose-dependent TNF $\alpha$ differences (Figure 5B) although proteomics data indicate an increase in protein subunits of CIV (COX5A) and CV (ATP5O) (Supplementary Table 10). Moreover, ROS levels were also unchanged by dose-dependent TNF $\alpha$ incubation in human neurons over 24 hours (Figure 5C). Thus, alterations in ROS signaling seems to be not attributable for apoptosis induction (Figure 4B), cell proliferation elevation (Figure 4A) and -signaling (Figure 5A).

\section{SiRNA-mediated knockdown of CREB prior to TNF $\alpha$ stimulation leads to less changed proteins and phospho-proteins compared to knockdown or $\mathrm{TNF} \alpha$ treatment alone in human neurons}

CREB is a transcription factor connecting a multitude of pathways related to neuronal metabolism/ proliferation, synaptic plasticity and mitochondrial function [21], that were affected targets in our HT22 cell study (Figures 1-3) accompanied by elevated levels of p-CREB (Figure 3C and 3D). Therefore, we performed a siRNA-mediated knockdown of CREB protein in human neurons prior to TNF $\alpha$ treatment to investigate the CREB/CREB signaling contribution toward the molecular mechanism of TNF $\alpha$. The siRNA treatment resulted in an average CREB knockdown efficiency of 50\% (siRNA5: 48\% and siRNA7: 53\% compared to allstar negative controls; $n=2$ ) as shown by immunoblotting (Supplementary Figure 2).

Controls (negative - Allstar transfection; positive $-\mathrm{H}_{2} \mathrm{O}_{2}$ stimulation) revealed no changes in signaling pathways both at protein (Allstar and $\mathrm{H}_{2} \mathrm{O}_{2}$ ) and phosphoprotein level (Allstar) (Figure 5A) whereas 20/185 proteins (Allstar $/ \mathrm{H}_{2} \mathrm{O}_{2}$ ) and 19/80 phospho-proteins (Allstar/ $\mathrm{H}_{2} \mathrm{O}_{2}$ ) were altered in their expression profile (Supplementary Table 10). Supplementary Tables 6-9 show the identifiable and quantifiable proteins and phospho-proteins. Only mTOR Signaling, Regulation of eIF4 and p70S6K Signaling, EIF2 Signaling and Signaling by Rho Family GTPases were deregulated on the phosphorylation status by $\mathrm{H}_{2} \mathrm{O}_{2}$ stimulation (Figure $5 \mathrm{~A}$ ).

SiRNA-mediated knockdown of CREB using two independent siRNAs approaches (siRNA5 and siRNA7)
A

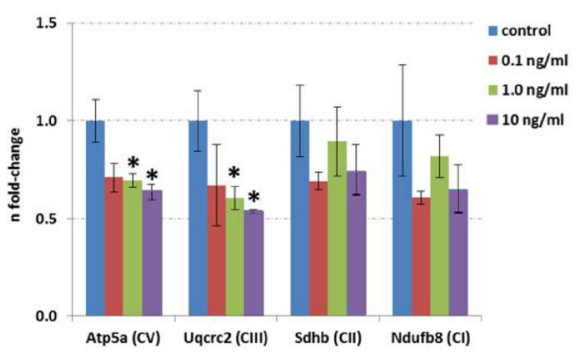

B

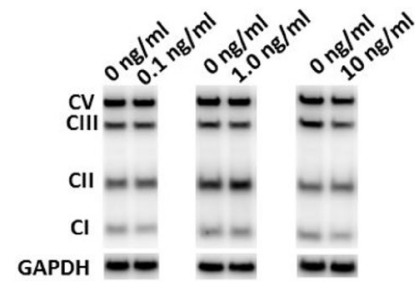

C

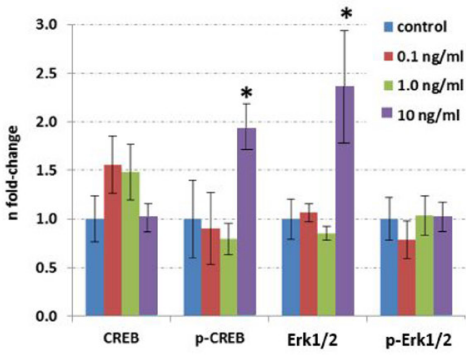

D

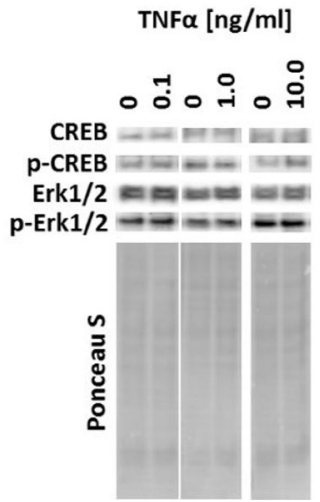

$E$

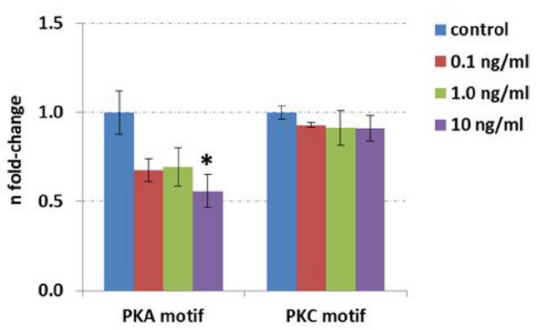

F

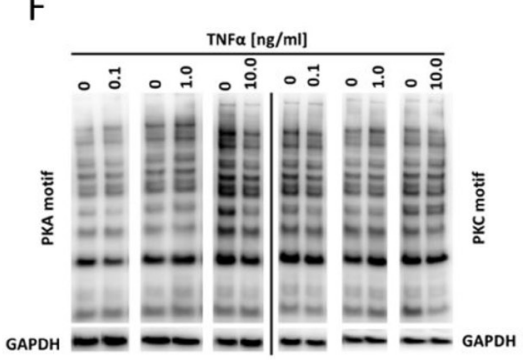

Figure 3: Immunoblotting of targets involved in mitochondrial function, synaptic plasticity and mTOR signaling in HT22 cells. Data from immunoblots of mitochondrial protein subunit expression (A), CREB, p-CREB, MAPK and p-MAPK (C) as well as PKA and PKC motif immunoblotting (E) are depicted from $0 \mathrm{ng} / \mathrm{ml}, 0.1 \mathrm{ng} / \mathrm{ml}, 1.0 \mathrm{ng} / \mathrm{ml}$ and $10.0 \mathrm{ng} / \mathrm{ml} \mathrm{TNF} \alpha$ stimulation over 24 hours in HT22 cells. The columns represent the fold-changes with standard errors of the mean [67]; $n=3 ;{ }^{*} p<0.05 ;{ }^{* *} p<0.01 ; * * * p<0.001$ (unpaired Student $\mathrm{s} t$-test). Normalization was performed against endogenous GAPDH for mitochondrial proteins as well as PKA and PKC motif immunoblotting; CREB, p-CREB, MAPK and p-MAPK were normalized against total lane intensity via Ponceau S staining. Representative visualisation of the immunoblotting data is shown in Panel $\mathbf{B}, \mathbf{D}$ and $\mathbf{F}$. 
affected CREB Signaling in Neurons and Signaling by Rho Family GTPases on the proteome and phospho-proteome level (siRNA5/siRNA7: proteome 4/2; phospho-proteome 29/43) (Figure 5A). Rho GTPases such as Rac1 and Cdc42 playing a fundamental role of CREB activity regulation [22-24]. CREB protein expression was significantly down-regulated as observed by immunoblotting (Supplementary Figure 2) whereas proteomics showed a tendency of downregulation (Supplementary Table 11). Further signaling pathways on the phospho-proteome level were affected by siRNAs but not by both simultaneously (Figure 5A) indicating only random hits. Most proteins and phospho-proteins overlap within the two siRNA knockdown approaches (Supplementary Table 10 - highlighted in green). Importantly, siRNAmediated CREB knockdown prior to $1.0 \mathrm{ng} / \mathrm{ml} \mathrm{TNF} \alpha$ stimulation does neither alter CREB signaling nor Rho Family GTPase signaling with $0 / 1$ altered proteins and 9/14 phospho-proteins for siRNA5+TNF $\alpha$ and siRNA7+TNF $\alpha$, respectively (Figure 5A, Supplementary
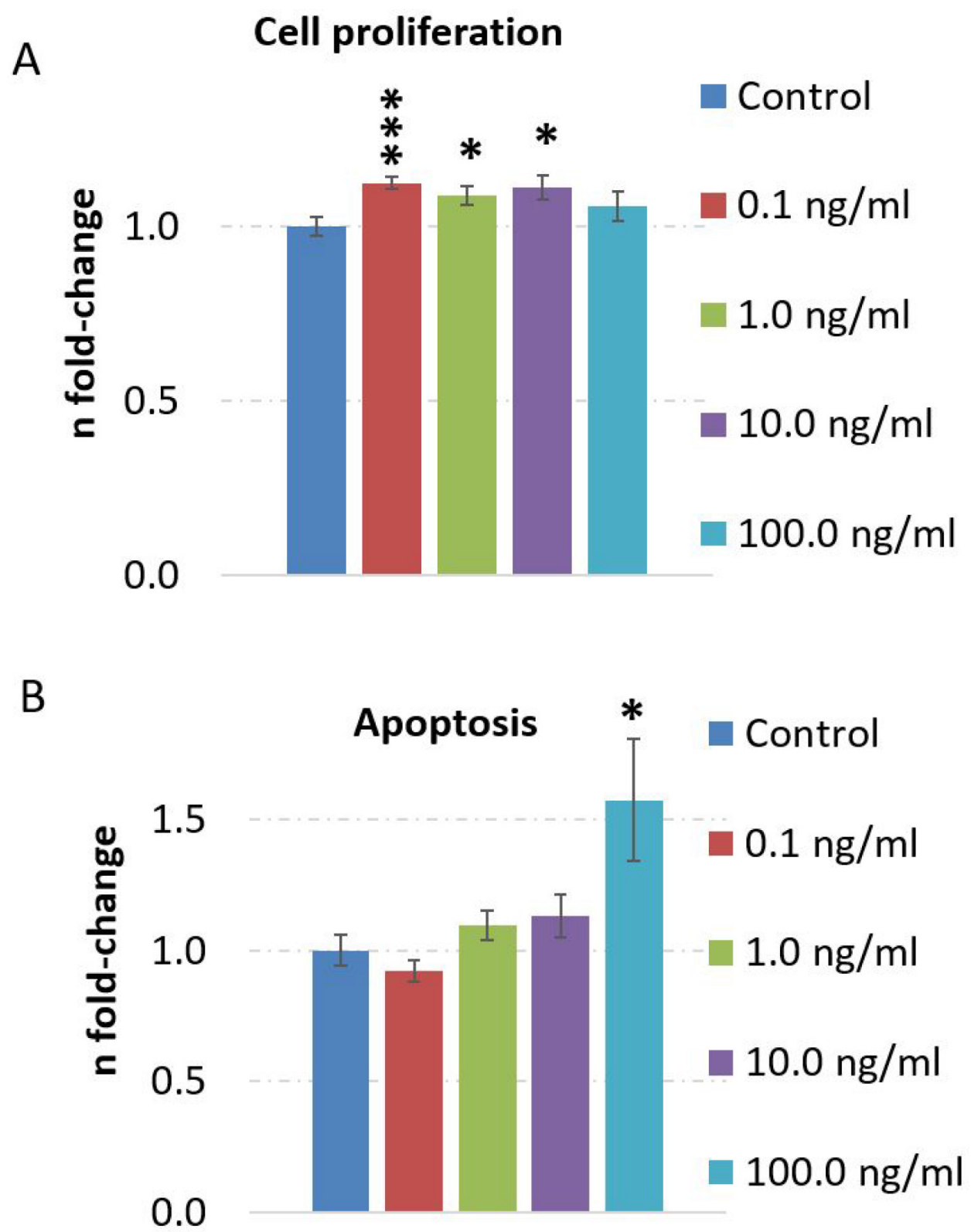

Figure 4: TNFa dose-dependent evaluation of cell proliferation and apoptosis in human neurons. Cell proliferation (A) and apoptosis (B) was quantified by CellTiter-Glo ${ }^{\circledR}$ Cell viability assay and Caspase-Glo ${ }^{\circledR} 3 / 7$ assay, respectively. Cells were cultured with a density of 7000 cells per well (96-well plates). The cells were stimulated with $0.1,1,10$ or $100 \mathrm{ng} / \mathrm{ml} \mathrm{TNF} \alpha$ over $24 \mathrm{hours}$ and untreated cells served as control. The figures show the fold-change and the standard error of the mean of 7-8 biological replicates per group. Statistical analysis was performed with unpaired Student's test; ${ }^{*} p<0.05 ;{ }^{*} p<0.01 ;{ }^{* * *} p<0.001$. 
Table 10). Immunoblotting of CREB demonstrated that the CREB protein levels were not changed by $1.0 \mathrm{ng} / \mathrm{ml}$ TNF $\alpha$ whereas siRNAs and $\mathrm{H}_{2} \mathrm{O}_{2}$ stimulation significantly reduces expression levels (Supplementary Figure 2). Importantly, Allstar and siRNAs+TNF $\alpha$ did not affect CREB expression (Supplementary Figure 2) correlating with our pathway analysis results (Figure 5A).

\section{Gene expression analysis reveals impairment in synaptic plasticity by TNF $\alpha$ stimulation in human neurons}

Next, we quantified 84 mRNAs related to synaptic plasticity to investigate the molecular mechanism of $\mathrm{TNF} \alpha$ in more detail. Thirteen gene transcripts were significantly down-regulated in their expression profile in human neurons treated with $1.0 \mathrm{ng} / \mathrm{ml} \mathrm{TNF} \alpha$ for 24 hours (Figure 6, Supplementary Table 12) including neuronal receptors (GABRA5, GRIA3, GRIN2A, GRM3), neurotrophic factors (BDNF, NTF4), cell-matrix modulators (ADAM10, MMP9, PCDH8), cellular stress responder (NFKB1) and neurotransmission regulators (CAMK2G, CREB1, GNAI1).

\section{TNF knockout mice have learning- and memory-related cognitive deficits after lipopolysaccharide-induced inflammation}

Our in vitro data indicated that TNF $\alpha$ may be important in the memory-related CREB signaling regulation in neurons. Thus, we questioned if knockout of TNF $\alpha$ in mice affects hippocampal-dependent learning and memory-related behaviour, which we did by exposing TNF $\alpha$ knockout and age-matched C57BL/6 mice to the Barnes maze. Both groups of mice quickly learned to locate the goal box and the latency times of

\section{A}

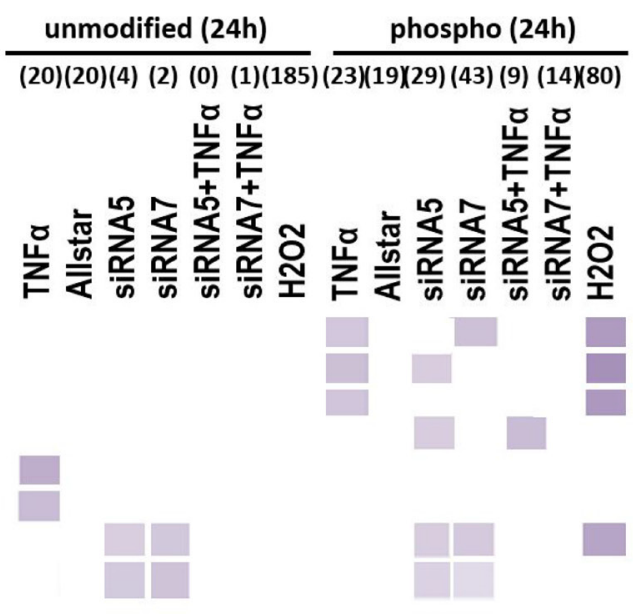

mTOR Signaling

Regulation of elF4 and p70S6K Signaling

EIF2 Signaling

Glycolysis

Oxidative Phosphorylation

Mitochondrial Dysfunction

Signaling by Rho Family GTPases

CREB Signaling in Neurons

B

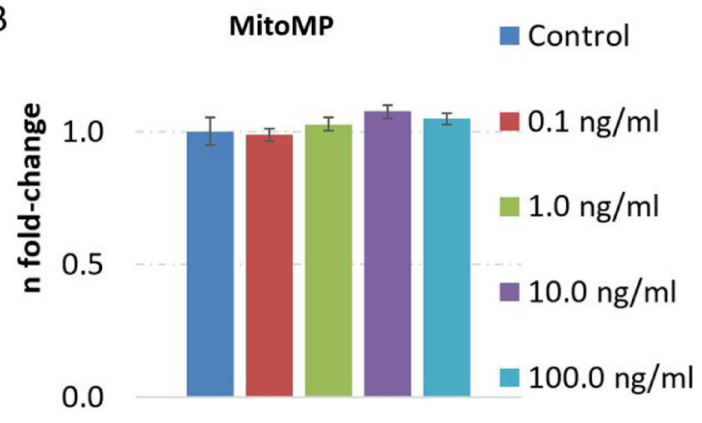

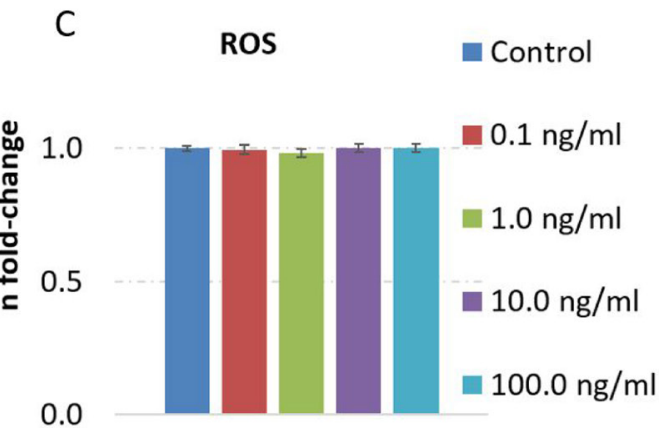

Figure 5: Analysis of signaling pathways from proteomics and phospho-proteomics experiments and quantification of mitochondrial membrane potential as well as reactive oxygen species levels in human neurons treated with $\mathrm{TNF} \alpha$. Altered signaling pathways in human neurons on the proteome and phospho-proteome using Ingenuity Pathway Analysis software are shown in panel (A) with the following treatment groups over 24 hours: TNF $\alpha$-dose of $1 \mathrm{ng} / \mathrm{ml}$ alone, Allstar as transfection control, siRNA5 and siRNA7 against CREB expression, siRNA5 and siRNA7 knockdown prior to 24 hours TNF $\alpha(1 \mathrm{ng} / \mathrm{ml})$ incubation and $\mathrm{H}_{2} \mathrm{O}_{2}$ incubation serving as positive control. High colour intensity represents high significance ( $p$ value) of the pathway. All coloured boxes have a $p$ value $\leq 0.05$; white boxes have a $p$ value $\geq 0.05$ and are not significantly changed; $n=2$ in each group. Panel (B and $\mathbf{C}$ ) show mitochondrial membrane potential (MitoMP) and reactive oxygen species (ROS) quantification from 7000 cells per well showing the fold-change and the standard error of the mean of 7-8 biological replicates per group. Statistical analysis was performed with unpaired Student's test; ${ }^{*} p<0.05$; $* * p<0.01 ; * * * p<0.001$. 


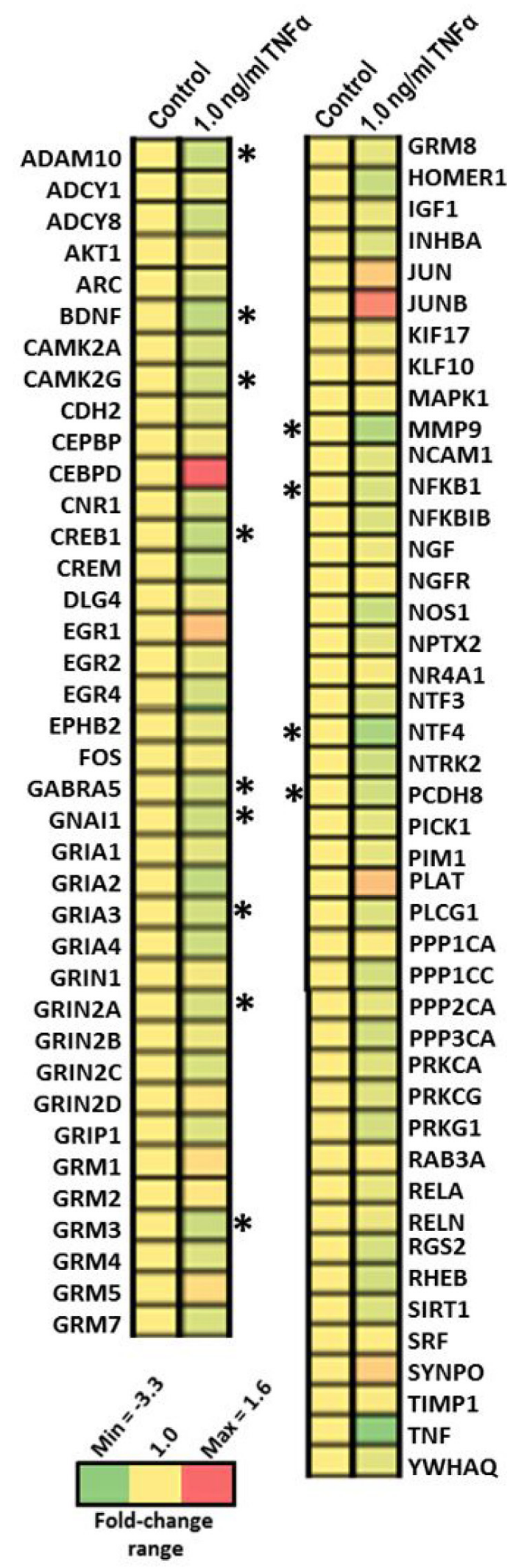

Figure 6: Quantification of the expression of genes involved in synaptic plasticity after $1.0 \mathrm{ng} / \mathrm{ml}$ TNF $\alpha$ stimulation over 24 hours in human neurons. Genes significantly changed in expression after $1.0 \mathrm{ng} / \mathrm{ml} \mathrm{TNF} \alpha$ stimulation for 24 hours compared to untreated human neurons using RT2 Profiler PCR Arrays (Qiagen) are shown. The table shows the genes which are significantly upregulated or down-regulated compared to controls in a heat-map presentation; ${ }^{*} p<0.05 ;{ }^{* *} p<0.01 ;{ }^{* * *} p<0.001$ (unpaired Student's $t$-test, $n=3)$. 
both groups were significantly decreased from day 2 of the 6 days the mice were tested, with no difference between the groups (Figure 7A), indicating that TNF $\alpha$ is not required for learning under normal conditions. Next, the TNF $\alpha$ knockout and C57BL/6 mice were challenged by inducing an inflammatory reaction by intraperitoneal LPS injection on days 7 and 4 prior to learning. The time of the injections was guided by observations obtained in the Morris water maze, showing that water mazeinduced learning promotes the survival of the granule cell precursors born a few days prior to induction of the learning experience [25]. As expected, LPS-injected mice displayed sickness behaviour that ceased 2-3 days after the last LPS-injection, which was 1-2 days prior to the time point where the mice were exposed to the Barnes maze protocol (taking place 4 days after the last LPSinjection). Interestingly, the LPS-injected TNF $\alpha$ knockout mice were extremely slow learners compared to the LPSinjected C57/BL6 mice (Figure 7B). Comparative analysis of toluidine blue stained coronal brain sections revealed no histoarchitectonic abnormalities in LPS-injected TNF $\alpha$ knockout compared to LPS-injected C57/BL6 mice. In particular, the hippocampus, which is involved in spatial learning and memory, had completely normal appearing granule and pyramidal cell layers and normal appearing neuropil layers along the entire rostrocaudal axis (data not shown). No changes in weight of the LPS-injected TNF $\alpha$ knockout or C57BL/6 mice were observed over the experiment (data not shown).

To explore the connection between TNF $\alpha$ and CREB signaling under physiological and LPS-induced inflammatory conditions, corresponding to those induced at 7 or 4 days prior to the Barnes maze-induced learning experience, we next challenged three-month-old C57BL/6 and $\mathrm{TNF} \alpha$ knockout mice to a single intraperitoneal injection with either LPS $(0.5 \mathrm{mg} / \mathrm{kg})$ or vehicle PBS and sacrificed them 4 hours after the injections corresponding to the time when inflammation peaks in the brain after LPS-injection [26]. Subsequently, the hippocampus was isolated and CREB, p-CREB immunoblotting was performed. Figure 7C-7E show a significant reduction of p-CREB levels in LPS-treated versus PBS-treated TNF$\mathrm{KO}$ mice in the hippocampus whereas CREB/p-CREB ratios were unchanged between $\mathrm{C} 57 \mathrm{BL} / 6$ and TNF-KO regardless of PBS and LPS-stimulation.

These data demonstrate that acute LPS-induced inflammation prior to learning affects hippocampusdependent learning ability in $\mathrm{TNF} \alpha$ knockout mice whereas modulation of CREB signaling seems to be an important molecular target in the LPS response.

\section{DISCUSSION}

To characterise neurodegenerative and proneurogenic properties of $\mathrm{TNF} \alpha$, we used quantitative proteomics and phospho-proteomics in HT22 neuronal cells and human embryonic stem cell-derived neurons to elucidate the differences in signaling pathway profiles that are associated with the distinct molecular properties of TNF $\alpha$. Furthermore, we performed experiments with siRNA-mediated CREB knockdown and behavioral learning analysis of TNF $\alpha$ knockout mice compared to wild type mice performance challenged with LPS.

HT22 cells are suitable as neuronal model to study TNF $\alpha$ signaling since they express both receptor subtypes for TNF $\alpha$ (TNFR1 and TNFR2) under normal culture conditions [13]. It has previously been shown that HT22 cells treated with $\mathrm{TNF} \alpha$ at concentrations of 1.0 and $10.0 \mathrm{ng} / \mathrm{ml}$ for 4 hours lead to up-regulation of Homerla and Egr2 [27], whereas both molecules are important in synaptic plasticity and memory formation. These data correlate well with our noted activation of CREBmediated signaling at a dose of $10.0 \mathrm{ng} / \mathrm{ml}$ over 24 hours as Homerla [28] and Egr2 [29] are CREB-dependent genes. As MAPK signaling is an upstream regulator of CREB signaling, the increase in MAPK at a dose of $10.0 \mathrm{ng} / \mathrm{ml} \mathrm{TNF} \alpha$ correlates with potential higher CREB activity. Scientific data indicate that an elevated MAPK signaling is involved in early stages of AD [30-32]. Importantly, the increased MAPK signaling in AD occurs via cellular stress arising from different factors such as $\mathrm{TNF} \alpha[33]$.

It has been reported that pretreatment ( 24 hours) of murine hippocampal slice cultures with $10.0 \mathrm{ng} /$ $\mathrm{mL}$ TNF $\alpha$ potentiated AMPA-induced neuronal death [18]. Moreover, Doll et al. noted that TNF $\alpha$ stimulation of HT22 cells decreased the cell viability. They also demonstrated that $\mathrm{TNF} \alpha$ exerts its neurotoxic effects through TNFR1 but not TNFR2 accompanied with apoptosis induction and decreased mitochondrial membrane potential [13]. We also observed a dosedependent alleviation in cell proliferation and induction of apoptosis by TNF $\alpha$ in HT22 cells. Importantly, only a dose of $10.0 \mathrm{ng} / \mathrm{ml} \mathrm{TNF} \alpha$ led to significant alterations of signaling pathways associated to cell metabolism, protein translation, mitochondrial function and synaptic plasticity. Notably, we found that mTOR, an important protein in regulating all these biological targets, is inhibited as revealed by bioinformatic analysis of proteome data. It has been shown that inhibition of mTOR is beneficial for synapse-dependent neuroprotection in transgenic AD mouse models reducing the levels of amyloid beta [34] and abrogating tau-mediated neurotoxicity by using systemic rapamycin [35]. Noteworthy, inhibition of mTOR signaling seems to be inversely correlated with $\mathrm{TNF} \alpha$ expression in an AD mouse model ( $\mathrm{APP}_{\mathrm{swe}} \mathrm{PS} 1_{\mathrm{dEg}}$ ) compared to wildtype control mice within the neocortex and hippocampus [36]. The elevation of synaptic plasticity-regulating and neuroprotective-acting p-CREB levels correlate well with the biological down-stream effects of indicated mTOR inhibition in HT22 cells at a dose of $10.0 \mathrm{ng} / \mathrm{ml} \mathrm{TNF} \alpha$ in our study. Furthermore, 
the reduction in PKA activity as revealed by motifimmunoblotting is also in agreement with mTOR inhibition as the pharmacological elevation of cAMP - an upstream inducer of PKA signaling - in mouse embryonic fibroblasts and HEK293 cells inhibits mTORC1 activation via a PKA-dependent mechanism [37].

Moreover, it has been reported that the bioenergetic effect of mTOR inhibition in neurons significantly preserves neuronal ATP levels, particularly when oxidative phosphorylation is impaired [38]. Our data indicated that oxidative phosphorylation is affected by $\mathrm{TNF} \alpha$ stimulation in HT22 cells influencing protein abundances of Complex I, -III, -IV and -V subunits. As the mitochondrial antibody cocktail used for immunoblotting consists only of the core proteins important for the assembly of the mitochondrial complex, the discrepancy between proteomics and immunoblotting data, particularly in the case of Complex $\mathrm{V}$, is not unexpected and has been observed before $[39,40]$. Neurons have a high ATP demand [41], and a reduction in ATP levels lead to profound decrease in neuronal viability [42]. Using a dopaminergic neuronal cell line (SH-SY5Y), it was also shown that TNF $\alpha$ alters Complex I activity, decreases ATP levels and increases ROS levels and mitochondrial turnover [43]. In contrary, we did not observe any changes in ROS level or MitoMP in human neurons treated with $\mathrm{TNF} \alpha$, which was seen
A

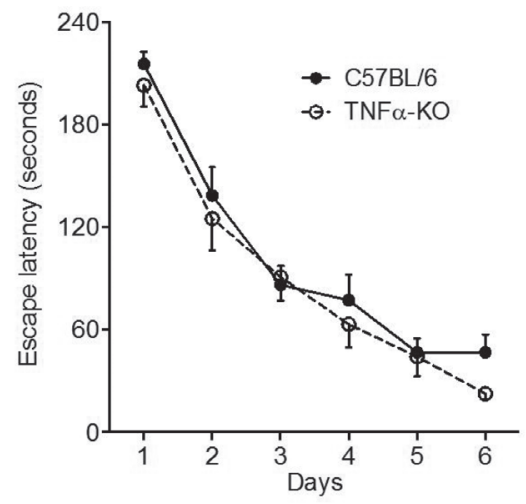

B

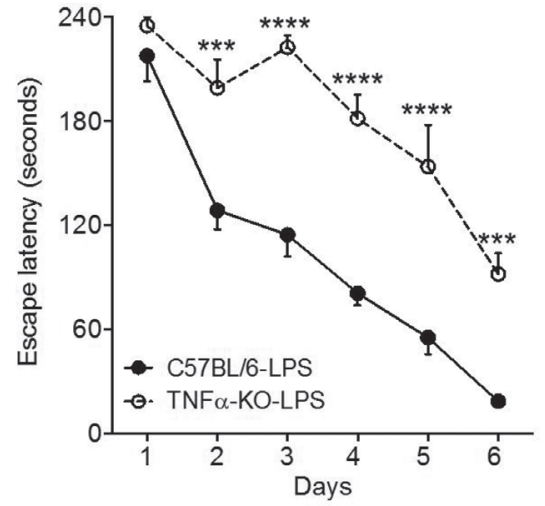

C LPS

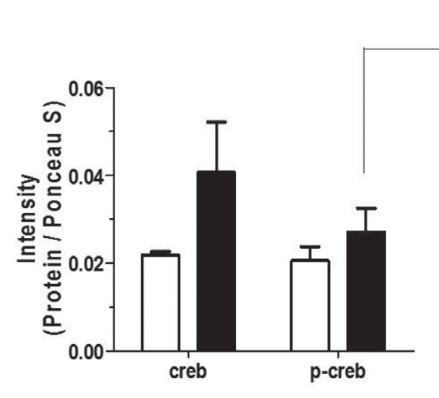

D

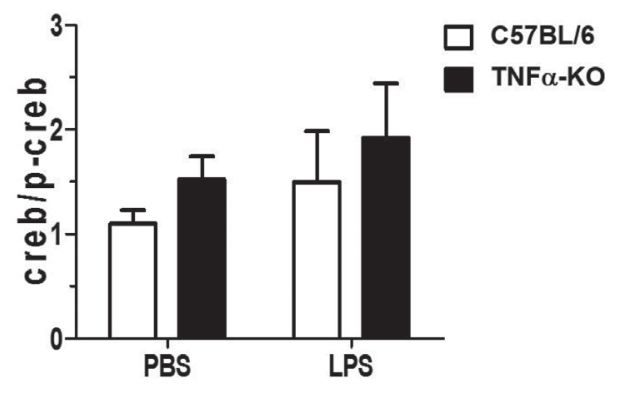

${ }^{*} P<0.05$

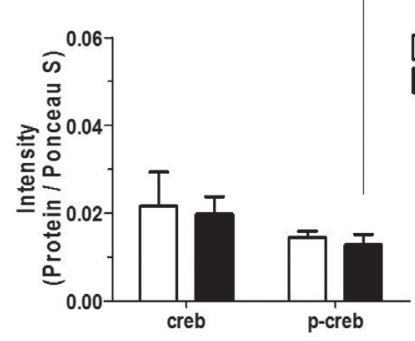

C57BL/6

TNF $\alpha-K O$

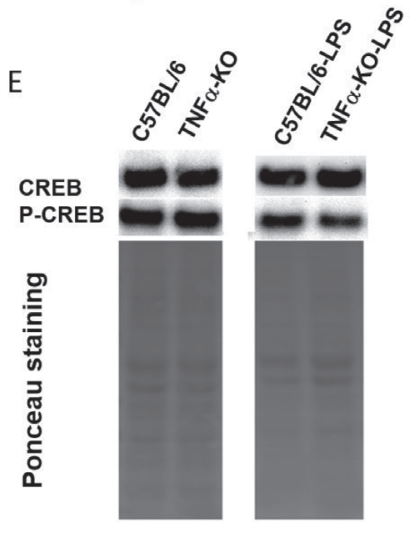

Figure 7: Neuroinflammation induced by LPS in TNF $\alpha$ knockout mice impairs cognitive ability. (A and B) Hippocampusdependent cognitive ability was explored in the Barnes maze in unmanipulated (A) and LPS-treated (B) female C57BL/6 (filled circles) and TNF $\alpha-\mathrm{KO}$ (open circles) mice. The escape latency represents the group mean of the average latency for 4 trials per mouse during the 6 days test period. Mice in (B) received an intraperitoneal injection of LPS (0.5 mg/kg of serum E-coli 0111:B4), 7 and 4 days prior to the Barnes maze learning experience. Error bars represent standard error of the mean [67]. (A) C57BL/6 mice $(n=16)$ and TNF $\alpha-\mathrm{KO}$ mice $(n$ $=11$ ) showed similar learning ability during the acquisition phase. Two-way ANOVA, repeated measures: Interaction, $\mathrm{F}(5,125)=0.45, P=$ 0.0010; Group, $\mathrm{F}(1,25)=0.81, P=0,3779$; Time, $\mathrm{F}(5,125)=74,36, P<0,0001$; Matching, $\mathrm{F}(5,125)=74.36, P<=0,0001$. Sidak's multiple comparison test: ns, for all comparisons. (B) In comparison, LPS injection seriously impaired the learning ability of the TNF $\alpha-K O$ mice $(n=8)$, but not in the C57BL/6 mice $(n=8)$. LPS-injected TNF $\alpha-K O$ mice consistently showed a significant higher latency in locating the goal box. Two-way ANOVA, repeated measures: Interaction, $\mathrm{F}(5,70)=4.68, P=0.0010$; Group, $\mathrm{F}(1,14)=50.85, P<0,0001$; Time, $\mathrm{F}(5,70)=59,23, P<0,0001$; Matching, $\mathrm{F}(14,70)=3.03, P=0,0011$. Sidak's multiple comparison test, $* * * P<0,001 ; * * * * P<0,0001$. $\mathrm{KO}$; knockout, ns; not significant, LPS; lipopolysaccharide. (C-E) Immunoblotting of CREB and p-CREB of hippocampus from threemonth-old C57BL/6 and TNF $\alpha$ knockout mice (male and female) to explore the connection between TNF $\alpha$ and CREB signaling under physiological and inflammatory conditions. Mice were treated with a single intraperitoneal injection of PBS or LPS $(0.5 \mathrm{mg} / \mathrm{kg}$ of serum E-coli 0111:B4) in sterile PBS and were sacrificed four hours after the injection. Intensities of protein CREB and p-CREB were normalised against respective total lane intensity of Ponceau staining. Statistical analysis was performed by using unpaired Student's $t$-test ( $n=3-6 /$ treatment group \& genotype, total number of mice: $n=17$ ). Bars represent the mean \pm SEM; Representative images of CREB and p-CREB immunoblotting and Ponceau stainings are shown in panel E. 
in HT22 cells by Doll et al. [13]. We believe that this is due to the intrinsic molecular and cellular differences of the used neuronal cell lines (SH-SY5Y and HT22) in comparison to our human stem cell-derived neurons.

The increase in cell proliferation that we observed at $0.1,1.0$ and $10.0 \mathrm{ng} / \mathrm{ml} \mathrm{TNF} \alpha$ in human neurons has also been found by others. Bernardino et al. demonstrated that the exposure of murine subventricular neuronal cultures to 1.0 and $10.0 \mathrm{ng} / \mathrm{ml}$ mouse or $1.0 \mathrm{ng} / \mathrm{ml}$ human recombinant $\mathrm{TNF} \alpha$ resulted in increased differentiation of cells displaying a neuronal-like calcium-mediated profile of responses, compared with the predominant profile of immature cells observed in non-treated control cultures [44]. Moreover, by using neutralizing antibodies for each $\mathrm{TNF} \alpha$ receptor, they found that the pro-neurogenic effect of $1.0 \mathrm{ng} / \mathrm{ml} \mathrm{TNF} \alpha$ is mediated via TNFR 1 activation. Interestingly, exposure of these cultures to $1.0 \mathrm{ng} / \mathrm{ml} \mathrm{TNF} \alpha$ induced cell proliferation, whereas 10.0 and $100.0 \mathrm{ng} / \mathrm{ml}$ TNF $\alpha$ induced apoptotic cell death [44]. The pro-survival molecular mechanism at $1.0 \mathrm{ng} / \mathrm{ml} \mathrm{TNF} \alpha$ stimulation in human neurons of our study may be attributable by decreased expression of p-BCLAF1 (Bcl-2-associated transcription factor 1) at Ser658 that is a positive regulator of apoptosis.

Noteworthy, our mRNA analysis revealed changes in several synaptic plasticity-regulating genes particular in expression levels of neuroreceptors in human neurons with $1.0 \mathrm{ng} / \mathrm{ml} \mathrm{TNF} \alpha$ stimulation over 24 hours. There, we noted that $C R E B$ was significantly down-regulated whereas CREB levels were unchanged by immunoblotting and proteomics experiments. CREB knockdown in human neurons led to changes in CREB-mediated signaling (Signaling of Rho family GTPases and CREB Signaling in Neurons) as expected. In comparison, CREB knockdown followed by $\mathrm{TNF} \alpha$ stimulation indicated a balance of CREB signaling as revealed by immunoblotting and signaling pathway analysis of proteomic and phospho-proteomic data. These data indicate that TNF $\alpha$ and CREB signaling are interconnected in neurons that could be based on the cAMP-responsive element (CRE) that $\mathrm{TNF} \alpha$ poses as reviewed elsewhere [45]. Thus, TNF $\alpha$ can modulate the signaling processes in neurons as well as learning and memory response to LPSinduced neuroinflammation as we demonstrated in our hippocampus-dependent behavioural testing.

To investigate how TNF affects learning ability, we exposed groups of TNF $\alpha$ knockout and age-matched $\mathrm{C} 57 \mathrm{BL} / 6$ mice to the Barnes maze. We did not observe any learning deficits in TNF $\alpha$ knockout mice using our Barnes maze protocol. This is in line with previous reports in TNF $\alpha$ knockout mice where no learning impairments are observed during the acquisition phase [46, 47]. We challenged the TNF $\alpha$ knockout mice and age-matched C57BL/6 mice with LPS-induced inflammation prior to learning. We observed clear learning impairments, after sickness behaviour had ceased, in the TNF $\alpha$ knockout mice, indicating that $\mathrm{TNF} \alpha$ plays a homeostatic role during neuroinflammation as has previously been suggested by others [48]. We also expected to find learning impairments in LPS-injected C57BL/6 mice, since LPS has been reported to impact on neurogenesis [49-51] and induce apoptosis of neurons in the subgranular zone [52]. However, we found that inflammation prior to learning essentially did not affect $\mathrm{C} 57 \mathrm{BL} / 6$ mice compared to age-matched $\mathrm{C} 57 \mathrm{BL} / 6$ mice. Others have shown learning deficits after LPS-injections in adult C57BL/6 mice using the Morris Water maze, yet, LPS injections were given 4 hours prior to learning [53] and the mice probably displayed sickness behaviour, which affects locomotor activity [26]. We did, however, find a slight learning impairment in LPS-treated 9-month-old C57BL/6 mice, in line with studies showing that aging causes a greater inflammatory response [54], which could cause greater impairments in learning ability. Importantly, we demonstrated that LPS- but not PBS-stimulation reduces $\mathrm{p}-\mathrm{CREB}$ levels in $\mathrm{TNF} \alpha-\mathrm{KO}$ mice but not in WT mice in the hippocampus 4 hours after stimulation. Phosphorylated CREB is the active form and is implicated in the regulation of development, protection, learning, memory and plasticity in the nerve system [55]. Thus, ameliorating the levels of p-CREB in the hippocampus affect CREB signaling that may explain the reduced memory and learning performance in our hippocampusdependent Barnes maze experiment. Whether or not these effects might also influence hippocampal neurogenesis, as might be inferred by studies by others [25], remains to be determined.

Our data suggest that the learning ability does not depend on TNF $\alpha$ but that TNF $\alpha$ preserves the learning and memory ability during episodes of neuroinflammation resembling the persistent neuroinflammation observed in AD. This may be based on modulation of CREB as revealed by our in vitro and in vivo studies, however, a deeper molecular analysis is necessary to clarify this connection in our model.

\section{MATERIALS AND METHODS}

\section{Cultivation of neuronal HT22 cells and human neurons}

HT22 cells (immortalised primary neurons from mouse hippocampus) were originally kindly provided by J. Lewerenz (Department of Neurology, University Hospital Hamburg-Eppendorf, Hamburg, Germany) [56] and were maintained in proliferation state in the laboratory of S. Tapio (Institute of Radiation Biology, Helmholtz Zentrum München, Munich, Germany) from where we received a frozen aliquot. The cells were grown in DMEM with GlutaMAX, 10\% New Born Calf Serum and 1\% $100 \mathrm{mM}$ sodium pyruvate in poly-L-ornithine coated T175 flasks without antibotics at $37^{\circ} \mathrm{C}$ and $5 \% \mathrm{CO}_{2}$ in air. Cells were incubated with $0 \mathrm{ng} / \mathrm{ml}$ (sterile water), $0.1 \mathrm{ng} / \mathrm{ml}, 1.0$ 
$\mathrm{ng} / \mathrm{ml}, 10.0 \mathrm{ng} / \mathrm{ml}$ and $100 \mathrm{ng} / \mathrm{ml} \mathrm{TNF} \alpha$ (active mouse TNF $\alpha$ full length protein - Abcam (ab9740)) for 30 minutes or 24 hours. Three biological replicates per condition and time point were used. Cells were washed with ice-cold phosphate-buffered saline (PBS). Subsequently, cells were scraped off in ice-cold PBS with phosphatase and protease inhibitors, centrifuged 2 minutes at $300 \times \mathrm{g}\left(4^{\circ} \mathrm{C}\right)$ and the supernatant was discarded. The cell pellets were dissolved in ice-cold PBS and centrifuged again. The supernatant was discarded and the cell pellets were frozen at $-20^{\circ} \mathrm{C}$ until further processing.

Human neurons were generated by differentiation of neural stem cells (NSCs) that were derived from human embryonic stem cell (XCell Science Inc). Cell expansion and differentiation into mature neurons was performed according to the company guidelines and as previously described [57]. In brief, the differentiation process went through three phases including proliferation, induction and maturation. NSCs were thawed and seeded into Geltrex (1:100) (Life Technologies) coated plates with Neurobasal Medium (Invitrogen) supplemented with $20 \mathrm{ng} / \mathrm{ml}$ bFGF (R\&D systems), 1× B27 (Invitrogen), $20 \mathrm{mM}$ MEM NEAA (Invitrogen), $20 \mathrm{mM}$ GlutaMax (Invitrogen) and 1\% Penicillin/Streptomycin (Invitrogen) and grown for several passages using StemPro ${ }^{\circledR}$ Accutase (Life Technologies) performed under routine cell culture conditions before starting the differentiation process.

For inducing NSCs into neuronal precursors, the proliferating cells were seeded at a density of 20000 cells/ $\mathrm{cm}^{2}$ into Poly-L-ornithin (PLO) (Sigma Aldrich) and Laminin (Sigma Aldrich) coated dishes in Neurobasal medium supplemented with the factors described above. At day 2, the medium was changed to Neural Induction Basal Medium (XCell Science) with Neuronal Induction Supplement A, B and C (XCell Science) and cells were induced for 6 days with medium change every second day. For the maturation phase, the neuronal precursor cells were grown into PLO/laminin coated dishes in Neuronal Maturation Basal Medium (XCell Science) supplemented with Neuronal Maturation Supplement A at a density of 35.000 cells $/ \mathrm{cm}^{2}$ and grown for 8 days. During the maturation process, the medium was changed every second day and cells were not passaged allowing them to fully differentiate into mature neurons.

Cells (untransfected, control-transfected or transfected for CREB knockdown) were incubated with $0 \mathrm{ng} / \mathrm{ml}$ (sterile water, negative control), $1.0 \mathrm{ng} / \mathrm{ml}$ $\mathrm{TNF} \alpha$ (active human TNF $\alpha$ full length protein - Abcam (ab83544)) or $50 \mu \mathrm{M} \mathrm{H} \mathrm{O}_{2}$ (positive control; 31642, Sigma) for 24 hours. Three biological replicates per condition and time point were used. Cells were washed with ice-cold PBS. Subsequently, cells were scraped off in ice-cold PBS with phosphatase and protease inhibitors, centrifuged 2 minutes at $300 \times \mathrm{g}\left(4^{\circ} \mathrm{C}\right)$ and the supernatant was discarded. The cell pellet was dissolved in ice-cold PBS and centrifuged again. The supernatant was discarded and the cell pellets were frozen at $-20^{\circ} \mathrm{C}$ until further processing.

\section{Immunofluorescence}

For double immunofluorescence staining, NSCs were grown in 24-well plates containing glass coverslips (VWR) essentially as described above regarding surface coating, medium and cell density. After differentiation, cells were fixed in 4\% paraformaldehyde (PFA; Sigma) in PBS for 25 min at room temperature (RT). For gammaaminobutyric acid (GABA) staining, cells were fixed in 4\% PFA and $0.05 \%$ glutaraldehyde (Sigma).

Cells were rinsed with $0.05 \mathrm{M}$ Tris-buffered saline (TBS) $/ 0.1 \%$ Triton-X-100 (Sigma), then preincubated with TBS $/ 5 \%$ goat serum (Gibco) according to the host of the secondary antibody, and incubated with a mixture of two of the following primary antibodies diluted in $\mathrm{TBS} / 5 \%$ goat serum for $24 \mathrm{hrs}$ at $4^{\circ} \mathrm{C}$. Antibodies were used at the following concentrations: glial fibrillary acidic protein (GFAP; rabbit anti-; DAKO) 1:4000; $\beta$-tub III (mouse anti; Sigma) 1:2000; GABA (rabbit anti-; Chemicon) 1:500 and Ki67 (mouse anti-; BD Pharmingen) 1:500 in TBS $/ 5 \%$ goat serum. Subsequently, cultures were incubated with a mixture of Alexa Fluor ${ }^{\circledR} 555$ conjugated anti-mouse IgG and Alexa Fluor ${ }^{\circledR} 488$ conjugated antirabbit IgG at 1:200 for two hrs at RT. Cell nuclei were counterstained with 4',6-diamidino-2-phenylindole (DAPI; Sigma) at $10 \mu \mathrm{M}$ in TBS. Cultures were mounted onto glass slides with Prolong ${ }^{\circledR}$ Gold mounting medium (Molecular Probes). Images were recorded using a Zeiss Axiophot epifluorescence microscope connected to a Leica DC300 camera and processed using Adobe ${ }^{\circledR}$ Photoshop ${ }^{\circledR}$ software.

\section{Transfection of human neurons}

RNA-oligonucleotides were used to knockdown CREB protein (Unspecific_AllStars_1 (FlexiTube siRNA premix 1027420, Qiagen) as negative control and Hs_CREB_5 (siRNA5) (SI00299894 - AACCAAGTTGTTGTTCAAGCT, Qiagen) and Hs_CREB_7 (siRNA7) (SI00299908 - AAGCCCAGCCACAGATTGCCA, Qiagen) for knockdown of target protein). Unspecific_AllStars_1 was dissolved in $625 \mu \mathrm{l}$ RNAse-free water $(10 \mu \mathrm{M}$ stock solution) whereas the siRNAs to knockdown CREB were dissolved in each $100 \mu \mathrm{l}$ RNAse-free water $(10 \mu \mathrm{M}$ stock solution). $5 \mu$ l of each solution was mixed in $250 \mu 1$ Neuronal maturation media. $15 \mu 1$ Lipofectamine RNAiMax (13778150, Thermo Fisher Scientific) was dissolved in $250 \mu \mathrm{l}$ serum-free Neuronal maturation media as well. Subsequently, $250 \mu 1$ of siRNA-containing media was mixed with $250 \mu \mathrm{l}$ lipofectamine containing media and incubated for 40 minutes at RT. The final siRNA/ FlexiTube siRNA concentration per $10 \mathrm{~cm}$ petri dish was 
50 pmol (500 $\mu 1$ siRNA-lipid media complex per well) with a total media volume of $10 \mathrm{ml}$. The transfection of human neurons started 24 hours before stimulation with/ without TNF $\alpha$.

\section{Cell viability and Caspase 3/7 activity assays}

For both HT22 cells and the human stem cellderived neurons, cell viability and caspase activity were determined using CellTiter-Glo ${ }^{\circledR}$ Cell viability assay and Caspase-Glo ${ }^{\circledR}$ 3/7 assay, respectively (both Promega). Cells were cultured as described above at a density of 2500 or 5000 (HT22) and 7000 cells per well (human neurons) in white polystyrene flat-bottomed 96-well plates. The cells were stimulated with $0.1,1,10$ or 100 $\mathrm{ng} / \mathrm{ml} \mathrm{TNF} \alpha$ and untreated cells served as control. After 24 hrs of stimulation, CellTiter-Glo or Caspase-Glo reagents were added to each well according to the manufacturer's instructions. After 10 min (CellTiter-Glo) or 30 min (Caspase-Glo) at RT, the luminescence signals were measured against medium (wells without cells) using a BMG fluostar Omega Plate reader (BMG Labtech).

\section{Reactive oxygen species detection and mitochondrial membrane potential assay}

Oxidative stress and mitochondrial membrane potential (MitoMP) were measured for the human stem cell-derived neurons with a reactive oxygen species (ROS) detection assay (Abcam) and a MitoMP assay (Cell Signaling). Cells were cultured as described above at a density of 7000 cells per well in white polystyrene flatbottomed 96-well plates [58]. The cells were stimulated with $0.1,1.0,10.0$ or $100.0 \mathrm{ng} / \mathrm{ml} \mathrm{TNF} \alpha$ and untreated cells served as control. For the ROS assay, after $24 \mathrm{hrs}$ of stimulation the cells were incubated for $60 \mathrm{~min}$ at $37^{\circ} \mathrm{C}$ with the ROS Red Dye working solution. Thereafter, some cells were treated with $10 \mu \mathrm{M}$ or $20 \mu \mathrm{M}$ DMSO for 15 min as positive controls whereas the fluorescence signal (Ex490/Em620, bottom optics) was measured against medium (wells without cells) using a BMG fluostar Omega Plate reader (BMG Labtech).

For the MitoMP assay, after $24 \mathrm{hrs}$ of stimulation the cells were incubated with $2 \mu \mathrm{M} \mathrm{JC}-1$ for $15 \mathrm{~min}$. Some non-stimulated cells were incubated with $50 \mu \mathrm{M}$ CCCP for 5 min before adding JC-1 serving as positive controls. Thereafter cells were washed with PBS and added PBS before measuring the fluorescence signal (Ex490/Em520) against medium (wells without cells) using a BMG fluostar Omega Plate reader (BMG Labtech).

\section{Cell lysis and protein reduction}

Cell pellets were lysed and reduced in $6 \mathrm{M}$ urea, $2 \mathrm{M}$ thiourea and $10 \mathrm{mM}$ DTT at RT. Afterwards, samples were diluted 10 times by adding $20 \mathrm{mM}$ TEAB, $\mathrm{pH}$ 7.5. After vortexing and sonication, a protein aliquot was taken out and stored at $-20^{\circ} \mathrm{C}$ for Western blotting. A total of $60 \mu \mathrm{g}$ protein per condition were used for mass spectrometrybased proteomics.

\section{Protein alkylation and enzymatic digestion}

A total of $60 \mu \mathrm{g}$ of proteins were alkylated in $20 \mathrm{mM}$ iodoacetamide (IAA) for 30 minutes in the dark at RT. Subsequently, trypsin (1:50 (w/w) trypsin:protein) was added and the solution was incubated overnight at $37^{\circ} \mathrm{C}$. Protein and peptide quantification was performed by fluorometric quantification (Qubit ${ }^{\mathrm{TM}}$ - Life Technologies). The peptide solution was dried in a vacuum centrifuge before TMT labelling.

\section{TMT10-plex labelling}

Three and two biological replicates were used for HT22 cells and human neurons, respectively. The labelling was performed according to manufacturer's instruction. The labelled peptides of each condition were mixed $1: 1: 1: 1: 1: 1: 1: 1: 1: 1$, dried down and stored for further enrichment and analysis.

\section{Enrichment and purification of phosphorylated peptides using $\mathrm{TiO} 2$}

The workflow is described in detail by Larsen et al. [59]. Briefly, the combined labelled peptides $(600 \mu \mathrm{g}$ peptides in total) were dissolved in $\mathrm{TiO}_{2}$ loading buffer $(80 \%$ acetonitrile $(\mathrm{ACN}), 5 \%$ trifluoroacetic acid (TFA) and $1 \mathrm{M}$ glycolic acid) and incubated with $3.6 \mathrm{mg}$ of $\mathrm{TiO}_{2}$ (titansphere $\mathrm{TiO}_{2}, 5 \mu \mathrm{m}$; a kind gift from GL Sciences, Japan) beads for 30 minutes at RT. The beads were sequentially washed with $\mathrm{TiO}_{2}$ loading buffer, $80 \%$ ACN $/ 1 \%$ TFA and $10 \%$ ACN $/ 0.1 \%$ TFA. Phosphorylated peptides were eluted with $1.5 \%$ ammonium hydroxide solution, $\mathrm{pH}$ 11.3, and dried. The flow-through was incubated again with $\mathrm{TiO}_{2}(1.8 \mathrm{mg})$ and processed as before and the two $\mathrm{TiO}_{2}$ beads approaches were combined. The unbound $\mathrm{TiO}_{2}$ fraction and the combined washing fractions contain unmodified peptides. All the eluates were dried and desalted on micro-columns before capillary hydrophilic interaction liquid chromatography (HILIC) fractionation.

\section{Sample desalting with $\mathrm{R} 2 / \mathrm{R} 3$ micro-column}

The samples were desalted before HILIC fractionation using home-made P200-tip-based columns packed with equal ratios of Poros R2 (Oligo R2 Reversed Phase Resin 1-1112-46, Applied Biosystems) and Poros R3 (OligoR3 Reversed Phase Resin 1-1339-03, Applied Biosystems) reversed-phase resin material. The end of the tip was blocked with $\mathrm{C}_{8}$ material (Model 2314, $3 \mathrm{~m}$ 
EmporeTM C8). The column was prepared by short centrifugation $(1000 \times \mathrm{g})$ of the R3 reversed-phase resin $(100 \% \mathrm{ACN})$. The column was equilibrated with $0.1 \%$ TFA and centrifuged again. The acidified samples were loaded onto the columns and washed / centrifuged three times with $0.1 \%$ TFA. Peptides were eluted with $60 \%$ $\mathrm{ACN}, 0.1 \%$ TFA and dried.

\section{HILIC fractionation}

The unmodified and phosphorylated peptide samples were fractionated prior to nano liquid chromatographytandem mass spectrometry (nLC-MS/MS) analysis using HILIC as described previously [60,61]. Peptides were dissolved in 90\% ACN, 0.1\% TFA (solvent B) and loaded onto a $450 \mu \mathrm{m}$ OD $\times 320 \mu \mathrm{m}$ ID $\times 17 \mathrm{~cm}$ micro-capillary column packed with TSK Amide-80 ( $3 \mu \mathrm{m}$; Tosoh Bioscience) using an Agilent 1200 Series HPLC (Agilent). The peptides were separated using a gradient from $100-60 \%$ solvent $\mathrm{B}(\mathrm{A}=0.1 \% \mathrm{TFA})$ in $30 \mathrm{~min}$ at a flowrate of $6 \mu \mathrm{l} / \mathrm{min}$. Fractions were collected every $1 \mathrm{~min}$ based on the UV chromatogram. Subsequently, the peptide fractions were dried by vacuum centrifugation.

\section{Reversed-phase nanoLC-ESI-MS/MS}

The peptides (resuspended in $0.1 \%$ formic acid (FA)) were automatically injected and loaded on a ReproSil-Pur C18 AQ (Dr. Maisch, AmmerbuchEntringen, Germany) in-house packed trap column $(2 \mathrm{~cm} \times 100 \mu \mathrm{m}$ inner diameter; $5 \mu \mathrm{m})$. The peptides were separated at $250 \mathrm{nl} / \mathrm{min}$ on an analytical ReproSil-Pur C18 AQ (Dr. Maisch, Ammerbuch-Entringen, Germany) packed in-house column $(17 \mathrm{~cm} \times 75 \mu \mathrm{m} ; 3 \mu \mathrm{m})$ by reversed phase chromatography which was operated on an EASY-nanoLC system (Thermo Fisher Scientific, Odense, Denmark). Mobile phase was $95 \%$ ACN/ $0.1 \%$ FA (B) and water $/ 0.1 \%$ FA (A). The gradient was from $1 \%$ to $30 \%$ solvent $\mathrm{B}$ in $80 \mathrm{~min}, 30-50 \%$ B in $10 \mathrm{~min}$, $50-100 \% \mathrm{~B}$ in $5 \mathrm{~min}$ and $8 \mathrm{~min}$ at $100 \% \mathrm{~B}$. The nanoLC was online connected to a Q Exactive HF Hybrid Quadrupole-Orbitrap mass spectrometer (Thermo Fisher Scientific) operating in positive ion mode and using datadependent acquisition. The Orbitrap acquired the full MS scan with an automatic gain control (AGC) target value of $3 \mathrm{e} 6$ ions and a maximum fill time of $100 \mathrm{~ms}$. Each MS scan was acquired at high-resolution (120,000 full-width half maximum (FWHM) at m/z 200 in the Orbitrap with a mass range of 400-1400 Da. The 12 most abundant peptide ions were selected from the MS for higher energy collision-induced dissociation (HCD) fragmentation (collision energy: $34 \mathrm{~V}$ ) if they were at least doubly charged. Fragmentation was performed at high resolution $(60,000 \mathrm{FWHM})$ for a target of $1 \mathrm{e} 5$ and a maximum injection time of $60 \mathrm{~ms}$ using an isolation window of $1.2 \mathrm{~m} / \mathrm{z}$ and a dynamic exclusion of $20 \mathrm{~s}$.

\section{Data analysis of mass spectrometry experiments}

Raw data were searched against the Swissprot database and Uniprot mouse/human reference database via Mascot (v2.3.02, Matrix Science) and Sequest HT search engines, respectively, using Proteome Discoverer (v1.4.1.14, Thermo Fisher Scientific). A precursor mass tolerance of $10 \mathrm{ppm}$ and a product ion mass tolerance of $0.02 \mathrm{Da}$ were applied allowing not more than one missed cleavage for trypsin. Fixed modifications included carbamidomethylation of Cys and TMT10-plex labeling for Lys and N-terminal. Variable modifications contained phosphorylation on Ser/Thr/Tyr. The TMT10plex datasets were quantified using the centroid peak intensity with the "reporter ions quantifier" node. To ensure a highconfident identification of peptides, we used the Mascot percolator algorithm ( $q$ value filter set to 0.01 ), Mascot and Sequest HT peptide rank 1 and a cut-off value of Mascot score $\geq 22$ as well as Sequest HT $\Delta$ Cn of 0.1. Moreover, a cut-off value of Xcorr score for charge states of $+1,+2,+3$ and +4 higher than 1.5, 2, 2.25 and 2.5, were considered for further analysis. Subsequently, these peptides were filtered against a Decoy database resulting into a false discovery rate (FDR) of 0.01 (FDR $<0.01$ ). Quantification was performed on the log2-values of the measured peptide reporter ion intensities and the data were normalized based on the median. Modified peptides were merged with the R Rollup function (http://www.omics.pnl. gov) allowing for one-hit-wonders and using the mean of the normalized intensities for each peptide. Quantification of proteins was obtained by merging the unmodified peptides with the R Rollup function considering at least 2 unique peptides by not allowing for one-hit-wonders and using the mean of the intensities. Subsequently, the mean over the experimental conditions for each peptide in each replicate was subtracted in order to merge the data from different replicates. PhosphoRS was used to confidently localise phosphorylation sites with a confidence filter of $95 \%$. Phosphorylated peptides were normalized based on the protein expression in each of the replicates including the proteins with only one unique peptide to ensure that deregulation occurred on post-translation modification (PTM) level and not on protein level. Deregulated proteins and phosphorylated proteins were regarded to be significantly deregulated if they fulfilled a $p$-value of $<0.01$ regarding HT22 cell study $(n=3)$. We applied combined limma and rank product tests [62], subsequently corrected for multiple testing according to Storey. In case of human neurons, a fold-change threshold of \pm 1.3 accompanied with a maximal standard deviation of 30\% was used $(n=2)$ due to sample generation limitations. These filtering parameters of proteomics data sets were successfully applied recently within in vitro/in vivo projects in the field of neuroscience $[23,40,63]$.

The mass spectrometry proteomics data have been deposited to the ProteomeXchange Consortium [64] via 
the PRIDE partner repository with the dataset identifier PXD005675 (username: reviewer88432@ebi.ac.uk, password: nNWGP0Vk).

\section{Bioinformatics analysis of protein classes and affected signaling pathways}

Deregulated proteins were categorised into protein classes using PANTHER (Protein Analysis Through Evolutionary Relationships) classification system software (http://www.pantherdb.org) and the general annotation from UniProt (http://uniprot.org). The analyses of affected signaling pathways from all deregulated proteins and PTM profile of proteins were performed independently with the INGENUITY Pathway Analysis [43] (http:// www.ingenuity.com) software tool that comprises curated information from databases of experimental and predictive origin, enabling discovery of highly represented functions and pathways. The mean of the ratios of all deregulated phosphorylated peptides per protein was used for signaling pathway analysis. Network analysis was performed by uploading separately the deregulated unmodified and phosphorylated proteins. We used only the database information of experimental and predictive origin regarding central nervous system to be confident about the potential affected signaling pathways. The IPA comparison analysis takes into account the signaling pathway rank according to the calculated $p$-value and reports it hierarchically. The software generates significance values ( $p$-values) between each biological or molecular event and the imported proteins based on the Fisher's exact test $(p \leq 0.05)$. Upstream regulator analysis performed by IPA software was used to get more information about pathway nodes that are overlapping by the uploaded deregulated lists of found hits. A z-score greater 2 or smaller than -2 was used as significance level.

\section{Quantification of proteins and phosphorylation- motifs by immunoblotting}

Protein extracts $(15 \mu \mathrm{g})$ were separated on $4-12 \%$ Bolt Bis-Tris gradient gels (NW04125Box, Novex) and transferred to polyvinylidene fluoride (PVDF) membranes via the TransBlot SD Semi-Dry Transfer Cell Blotter system (Biorad). The protein content on the membranes was visualised with Ponceau S. The membranes were incubated in blocking buffer (5\% milk) washed and incubated overnight at $4^{\circ} \mathrm{C}$ with primary antibody dilutions as recommended by the manufacturer (PhosphoPKC Substrate Motif (R/KXpSX(R/K) MultiMab Rabbit Monoclonal Antibody - \#6967, Cell Signaling; Phospho-PKA Substrate (RRXS*/T*) (100G7E) Rabbit Monoclonal Antibody - \#9624, Cell Signaling; rabbit polyclonal antibody against p44/42 MAPK (Erk1/2) \#9102, Cell Signaling; rabbit polyclonal antibody against phospho-p44/p42 MAPK (Erk1/2) (Thr202/Tyr204) -
\#9101, Cell Signaling; goat polyclonal antibody against GAPDH - ab9483, Abcam; murine monoclonal antibody against CREB (clone 86B10) - \#9104, Cell Signaling; rabbit monoclonal antibody against phospho-CREB (Ser133) (clone 87G3) - \#9198, Cell Signaling; total OXPHOS murine monoclonal antibody cocktail against CV-ATP5A, CIII-UQRC2, CII-SDHB and CI-NDUFB8 ab110413, Abcam).

The blots were washed and incubated with horseradish peroxidase-conjugated secondary antibody (anti-rabbit IgG, HRP-linked antibody - \#7074, Cell Signaling, anti-mouse IgG, HRP-linked antibody ab6728, Abcam or anti-goat IgG, HRP-linked antibody ab6741, Abcam) in $5 \%$ milk or $3 \%$ bovine serum albumin (BSA; for phospho antibodies) for 2 hours. Subsequently, blots were washed and developed with ECL system (Luminata $^{\mathrm{TM}}$ Forte Western HRP Substrate, WBLUF0100, Millipore) using standard protocol from the manufacturer. Immunoblots were considered for quantification if (i) the pattern and intensity of lanes stained with PonceauS were equal and total lane intensity of the PonceauS-stained proteins was similar within the biological replicates. For phospho-motif immunoblots, the total lane intensity was selected as a representative indicator of global changes in PKA- and PKC-phospho motifs. Immunoblots were quantified with TotalLab TL100 software (www.totallab. com) using software-suggested background correction. Each band was normalised against the total lane intensity obtained by Ponceau S or against GAPDH that was not changed during our proteomics analysis. Fold-changes were calculated between TNF $\alpha$-stimulated and control samples. Three biological replicates were used for statistical analysis (Student's $t$-test, unpaired) with a significance threshold of 0.05 .

\section{Isolation of total RNA and pathway-focused gene expression analysis related to synaptic plasticity via quantitative PCR}

Total RNA from human neurons (control and $1.0 \mathrm{ng} / \mathrm{ml} \mathrm{TNF} \alpha$ for 24 hours; $n=3$ ) was isolated and purified by mirVana ${ }^{\mathrm{TM}}$ Isolation Kit (Ambion) according to the manufacturer's instructions. Total RNA was eluted with nuclease-free water. The optical density (OD) ratio of 260/280 was measured using a Nanodrop spectrophotometer (PeqLab Biotechnology); it ranged between 1.9 and 2.1. Eluates were stored at $-20^{\circ} \mathrm{C}$ until further analysis.

The RNA isolates (100 ng) were used to quantify the gene expression of 84 mRNA transcripts related to synaptic plasticity (RT2 Profiler Mouse Synaptic Plasticity - PAMM-126Z, Qiagen) according to the manufacturer's protocol on a StepOnePlus device (Applied Biosystems). The relative expression of each mRNA was normalised against the average $\mathrm{Ct}$ value of 5 reference genes (ACTB, B2M, GAPDH, HPRT1 and RPLP0) using the equation 
$2^{-\Delta \Delta \mathrm{Ct}}$, where $\Delta \Delta \mathrm{Ct}=\Delta \mathrm{Ct}_{\mathrm{TNF} \alpha}-\Delta \mathrm{Ct}_{\text {control }}$ and $\Delta \mathrm{Ct}=$ $\mathrm{Ct}_{\text {target-mRNA }}-\mathrm{Ct}_{\text {average-of-5-reference-genes }}$. Gene expression changes were considered significant if they reached a $p$-value of $\leq$ 0.05 (Student's $t$-test, unpaired). Three biological replicates were used in each group (control and $1.0 \mathrm{ng} / \mathrm{ml} \mathrm{TNF} \alpha$ ).

\section{Behavioural and molecular analysis of TNFa knockout and C57BL/6 mice}

\section{Mice}

For this experiment all mice used were 9-month-old female mice. TNF $\alpha$ knockout mice [8, 65] were purchased at Jackson Laboratories (USA) and bred on a C57BL/6 background. Female C57BL/6 mice were purchased from Taconic A/S (Denmark) except from a group of 9-month-old C57BL/6 mice, which was purchased from Harlan Laboratories (Netherlands). Mice were housed in the Biomedical Laboratory at the University of Southern Denmark. All experiments were conducted under permission from the Danish Ethical Animal Care Committee (Permissions no. 2011/562-67 and 2011/5611950).

\section{Barnes maze experiment - LPS treatment}

The effect of TNF $\alpha$ on the learning ability was studied in TNF $\alpha$ knockout $(n=11)$ mice using C57BL/6 mice $(n=16)$ as controls. Neuroinflammation was induced by intraperitoneal injection of TNF $\alpha$ knockout $(n=8)$ and C57BL/6 mice $(n=8)$ with lipopolysaccharide (LPS) (Serum E-coli 0111:B4, Sigma) injections (i.p) at a dose of $0.5 \mathrm{mg} / \mathrm{kg}$ at day 7 and 4 prior to learning.

\section{Barnes maze experiment - behaviour analysis}

The Barnes maze [66] was used to study the ability of $\mathrm{C} 57 \mathrm{BL} / 6$ and $\mathrm{TNF} \alpha$ knockout mice to learn during the acquisition phase as described recently [67]. The Barnes maze is a $92 \mathrm{~cm}$ diameter maze with 20 holes distributed around the perimeter (Panlab Spain) and the testing was performed under a high power lamp source to motivate the mice. Two weeks prior evaluation of mice on the Barnes maze, the mice were individually housed and placed in a room reserved to behavioural assessment. Mice were tested in the Barnes maze for 6 consecutive days with 4 trials per day. The location of the goal box and distal spatial cues were constant during the experiment. Each mouse was placed within a cylinder in the middle of the maze for 30 seconds. The mouse was then allowed 4 minutes to find the goal box and, if not found within 4 minutes, the mouse was gently guided towards the goal box by hand. When the mouse located the goal box itself, it was kept in timeout in the box for the remaining time of the 4 minutes. The latency time is the time the mouse spends on the maze before finding the goal box. The maze was cleaned with $70 \%$ ethanol between each mouse. Statistical analysis was performed using Prism (GraphPad Software, version 6). Data are presented as mean \pm standard error of the mean.
Data were analysed using repeated measures (RM) twoway analysis of variance (ANOVA) followed by Sidak's Multiple Comparison Test. Differences were considered significant if $P \leq 0.05$. $P$-values are indicated as follows: $P \leq 0.05:^{*}, P<0.01:^{* *}, P<0.001$ : $^{* *}$, and $P<0.0001$ : $* * * *$.

\section{Histology}

Mice were euthanized by an overdose Pentobarbital following by transcardial perfusion with $5 \mathrm{ml}$ PBS and $20 \mathrm{ml} \mathrm{4 \%}$ PFA. The brains were thereafter placed in $20 \%$ sucrose overnight, and frozen. Brains were stored at $-20^{\circ} \mathrm{C}$ until they were sectioned in a cryostate into $35 \mathrm{~mm}$ thick coronal. Parallel sections spanning the entire forebrain were stained with toluidine blue [8].

\section{CREB and p-CREB immunoblotting of hippocampus}

Three-month-old C57BL6 wild-type and TNFa knockout littermate mice were used to explore the connection between TNF $\alpha$ and CREB signaling under physiological and inflammatory conditions $(n=3-6 /$ treatment group \& genotype, $n=17$ ). Mice received a single intraperitoneal injection with either sterile PBS or $0.5 \mathrm{mg} / \mathrm{kg}$ LPS (Serum E-coli 0111:B4, Sigma, Denmark) in sterile PBS (injection volume $\sim 150 \mu \mathrm{L}$ ). Four hours after the injections, the mice were killed by cervical dislocation and their brains were immediately removed and dissected on a Petri dish filled with ice. The left hippocampus was heat-stabilized using the StabilizorTM T1 (Denator), and subsequently frozen on dry-ice for immunoblotting as described earlier.

\section{CONCLUSIONS}

This study shows that several molecular targets and signaling pathways induced by TNF $\alpha$ in neurons resemble those of AD pathology. It may suggest that TNF $\alpha$ functions as a contributing factor to this neurodegenerative disease but at the same time has neuroprotective properties regulating learning and memory formation under neuroinflammatory conditions resembling those noted in AD.

\section{Abbreviations}

AMPA; $\quad \alpha$-amino-3-hydroxy-5-methyl-4isoxazolepropionic acid, AD; Alzheimer disease, ANOVA; analysis of variance, $\mathrm{AGC}$; automatic gain control, $\mathrm{ACN}$; acetonitrile, BSA; bovine serum albumin, FA; formic acid, FDR; false discovery rate, FWHM; full-width half maximum, GABA; gamma-aminobutyric acid, HILIC; hydrophilic interaction liquid chromatography, HCD; higher energy collision-induced dissociation, IPA; Ingenuity Pathway Analysis, IAA; iodoacetamide, LPS; lipopolysaccharide, LC-MS/MS; liquid chromatographytandem mass spectrometry, MitoMP; mitochondrial membrane potential, NMDA; N-methyl-D-aspartate, NSCs; neural stem cells, OD; optical density PBS; 
phosphate buffered saline, PLO; poly-L-ornithin, PVDF; polyvinylidene fluoride, PFA; paraformaldehyde, PTM; post-translation modification, RM; repeated measures, RT; room temperature, ROS; reactive oxygen species, SEM; standard error of the mean, TFA; trifluoroacetic acid, TBS; Tris-buffered saline

\section{Author contributions}

Conceived, designed and managed the project: SJK; Performed experiments: PJ, PL, CLM, AAB, AMK, KLL, AM; Contributed reagents: MRL, BF; Analysed the data: SJK, PJ, PL, CLM, AAB; Wrote the paper: SJK, MRL, $\mathrm{BF}, \mathrm{PJ}, \mathrm{CLM}$.

\section{ACKNOWLEDGMENTS AND FUNDING}

The research leading to these results was supported by a grant from SDU2020 (COPING AD - Collaborative Project on the Interaction between Neurons and Glia in Alzheimer's Disease) (BF, MRL). This work was also partly supported by a generous grant from the VILLUM Foundation to the VILLUM Center for Bioanalytical Sciences at the University of Southern Denmark. Moreover, this work was supported by Sino-Danish Center (SDC) for Education and Research (CLM, BF) and the Danish Medical Research Council (AAB, BF).

We would like to thank Carolin Thomas and Julia Schwing for their work during their stay at our institute. We thank J. Lewerenz and S. Tapio for sharing HT22 cells.

\section{CONFLICTS OF INTEREST}

The authors declare no competing interests.

\section{REFERENCES}

1. Fillit H, Ding WH, Buee L, Kalman J, Altstiel L, Lawlor B, Wolf-Klein G. Elevated circulating tumor necrosis factor levels in Alzheimer's disease. Neurosci Lett. 1991; 129:318-20.

2. Holmes C, Cunningham C, Zotova E, Woolford J, Dean C, Kerr S, Culliford D, Perry VH. Systemic inflammation and disease progression in Alzheimer disease. Neurology. 2009; 73:768-74. https://doi.org/10.1212/ WNL.0b013e3181b6bb95.

3. Nadeau S, Rivest S. Role of microglial-derived tumor necrosis factor in mediating CD14 transcription and nuclear factor kappa B activity in the brain during endotoxemia. J Neurosci. 2000; 20:3456-68.

4. Allan SM, Rothwell NJ. Cytokines and acute neurodegeneration. Nat Rev Neurosci. 2001; 2:734-44. https://doi.org/10.1038/35094583.

5. Schwartz M, Shechter R. Systemic inflammatory cells fight off neurodegenerative disease. Nat Rev Neurol. 2010; 6:405-10. https://doi.org/10.1038/nrneurol.2010.71.
6. Butchart J, Brook L, Hopkins V, Teeling J, Puntener U, Culliford D, Sharples R, Sharif S, McFarlane B, Raybould R, Thomas R, Passmore P, Perry VH, et al. Etanercept in Alzheimer disease: A randomized, placebocontrolled, double-blind, phase 2 trial. Neurology. 2015; 84:2161-8. https://doi.org/10.1212/wnl.0000000000001617.

7. Ruspi G, Schmidt EM, McCann F, Feldmann M, Williams RO, Stoop AA, Dean JL. TNFR2 increases the sensitivity of ligand-induced activation of the p38 MAPK and NF-kappaB pathways and signals TRAF2 protein degradation in macrophages. Cell Signal. 2014; 26:683-90. https://doi.org/10.1016/j.cellsig.2013.12.009.

8. Lambertsen KL, Clausen BH, Babcock AA, Gregersen R, Fenger C, Nielsen HH, Haugaard LS, Wirenfeldt M, Nielsen M, Dagnaes-Hansen F, Bluethmann $H$, Faergeman NJ, Meldgaard M, et al. Microglia protect neurons against ischemia by synthesis of tumor necrosis factor. J Neurosci. 2009; 29:1319-30. https://doi. org/10.1523/JNEUROSCI.5505-08.200929/5/1319.

9. McCoy MK, Tansey MG. TNF signaling inhibition in the CNS: implications for normal brain function and neurodegenerative disease. J Neuroinflammation. 2008; 5:45. https://doi.org/10.1186/1742-2094-5-45.

10. Habbas S, Santello M, Becker D, Stubbe H, Zappia G, Liaudet N, Klaus FR, Kollias G, Fontana A, Pryce CR, Suter T, Volterra A. Neuroinflammatory TNFalpha impairs memory, via astrocyte signaling. Cell. 2015; 163:1730-41. https://doi.org/10.1016/j.cell.2015.11.023.

11. Beattie EC, Stellwagen D, Morishita W, Bresnahan JC, Ha BK, Von Zastrow M, Beattie MS, Malenka RC. Control of synaptic strength by glial TNFalpha. Science. 2002; 295:2282-5. https://doi.org/10.1126/science.1067859.

12. Pribiag H, Stellwagen D. TNF-alpha downregulates inhibitory neurotransmission through protein phosphatase 1-dependent trafficking of $\mathrm{GABA}(\mathrm{A})$ receptors. J Neurosci. 2013; 33:15879-93. https://doi.org/10.1523/ jneurosci.0530-13.2013.

13. Doll DN, Rellick SL, Barr TL, Ren X, Simpkins JW. Rapid mitochondrial dysfunction mediates TNF-alpha-induced neurotoxicity. J Neurochem. 2015; 132:443-51. https://doi. org/10.1111/jnc. 13008 .

14. Kawamoto EM, Scavone C, Mattson MP, Camandola S. Curcumin requires tumor necrosis factor alpha signaling to alleviate cognitive impairment elicited by lipopolysaccharide. Neurosignals. 2013; 21:75-88. https:// doi.org/10.1159/000336074.

15. Hsu H, Shu HB, Pan MG, Goeddel DV. TRADD-TRAF2 and TRADD-FADD interactions define two distinct TNF receptor 1 signal transduction pathways. Cell. 1996; 84:299-308.

16. Quintana A, Giralt M, Rojas S, Penkowa M, Campbell IL, Hidalgo J, Molinero A. Differential role of tumor necrosis factor receptors in mouse brain inflammatory responses in cryolesion brain injury. J Neurosci Res. 2005; 82:701-16. https://doi.org/10.1002/jnr.20680. 
17. Declercq W, Denecker G, Fiers W, Vandenabeele P. Cooperation of both TNF receptors in inducing apoptosis: involvement of the TNF receptor-associated factor binding domain of the TNF receptor 75. J Immunol. 1998; 161:390-9.

18. Bernardino L, Xapelli S, Silva AP, Jakobsen B, Poulsen FR, Oliveira CR, Vezzani A, Malva JO, Zimmer J. Modulator effects of interleukin-1beta and tumor necrosis factor-alpha on AMPA-induced excitotoxicity in mouse organotypic hippocampal slice cultures. J Neurosci. 2005; 25:6734-44. https://doi.org/10.1523/jneurosci.1510-05.2005.

19. Lesiak A, Pelz C, Ando H, Zhu M, Davare M, Lambert TJ, Hansen KF, Obrietan K, Appleyard SM, Impey S, Wayman GA. A genome-wide screen of CREB occupancy identifies the RhoA inhibitors Par6C and Rnd3 as regulators of BDNF-induced synaptogenesis. PLoS One. 2013; 8:e64658. https://doi.org/10.1371/journal.pone.0064658.

20. Shahbazian D, Roux PP, Mieulet V, Cohen MS, Raught B, Taunton J, Hershey JW, Blenis J, Pende M, Sonenberg N. The mTOR/PI3K and MAPK pathways converge on eIF4B to control its phosphorylation and activity. Embo j. 2006; 25:2781-91. https://doi.org/10.1038/sj.emboj.7601166.

21. Cheng A, Hou Y, Mattson MP. Mitochondria and neuroplasticity. ASN Neuro. 2010; 2:e00045. https://doi. org/10.1042/an20100019.

22. Wayman GA, Davare M, Ando H, Fortin D, Varlamova O, Cheng HY, Marks D, Obrietan K, Soderling TR, Goodman RH, Impey S. An activity-regulated microRNA controls dendritic plasticity by down-regulating p250GAP. Proc Natl Acad Sci USA. 2008; 105:9093-8. https://doi. org/10.1073/pnas.0803072105.

23. Kempf SJ, Casciati A, Buratovic S, Janik D, von Toerne C, Ueffing M, Neff F, Moertl S, Stenerlow B, Saran A, Atkinson MJ, Eriksson P, Pazzaglia S, et al. The cognitive defects of neonatally irradiated mice are accompanied by changed synaptic plasticity, adult neurogenesis and neuroinflammation. Mol Neurodegener. 2014; 9:57. https:// doi.org/10.1186/1750-1326-9-57.

24. Yang EJ, Yoon JH, Min DS, Chung KC. LIM kinase 1 activates cAMP-responsive element-binding protein during the neuronal differentiation of immortalized hippocampal progenitor cells. J Biol Chem. 2004; 279:8903-10. https:// doi.org/10.1074/jbc.M311913200.

25. Dupret D, Fabre A, Dobrossy MD, Panatier A, Rodriguez JJ, Lamarque S, Lemaire V, Oliet SH, Piazza PV, Abrous DN. Spatial learning depends on both the addition and removal of new hippocampal neurons. PLoS Biol. 2007; 5:e214. https://doi.org/10.1371/journal.pbio.0050214.

26. Cunningham C, Sanderson DJ. Malaise in the water maze: untangling the effects of LPS and IL-1beta on learning and memory. Brain Behav Immun. 2008; 22:1117-27. https:// doi.org/10.1016/j.bbi.2008.05.007.

27. Karrer M, Lopez MA, Meier D, Mikhail C, Ogunshola OO, Muller AF, Strauss L, Tafti M, Fontana A. Cytokineinduced sleep: Neurons respond to TNF with production of chemokines and increased expression of Homerla in vitro. Brain Behav Immun. 2014. https://doi. org/10.1016/j.bbi.2014.11.008.

28. Naidoo N, Ferber M, Galante RJ, McShane B, Hu JH, Zimmerman J, Maislin G, Cater J, Wyner A, Worley P, Pack AI. Role of Homer proteins in the maintenance of sleep-wake states. PLoS One. 2012; 7:e35174. https://doi. org/10.1371/journal.pone.0035174.

29. Li C, Dong S, Wang H, Hu Y. Microarray analysis of gene expression changes in the brains of NR2B-induced memory-enhanced mice. Neuroscience. 2011; 197:121-31. https://doi.org/10.1016/j.neuroscience.2011.08.031.

30. Sun A, Liu M, Nguyen XV, Bing G. P38 MAP kinase is activated at early stages in Alzheimer's disease brain. Exp Neurol. 2003; 183:394-405.

31. Sanderson TM, Hogg EL, Collingridge GL, Correa SA. Hippocampal metabotropic glutamate receptor longterm depression in health and disease: focus on mitogenactivated protein kinase pathways. J Neurochem. 2016; 139: 200-14. https://doi.org/10.1111/jnc.13592.

32. Kim EK, Choi EJ. Compromised MAPK signaling in human diseases: an update. Arch Toxicol. 2015; 89:867-82. https://doi.org/10.1007/s00204-015-1472-2.

33. Bhaskar K, Maphis N, Xu G, Varvel NH, KokikoCochran ON, Weick JP, Staugaitis SM, Cardona A, Ransohoff RM, Herrup K, Lamb BT. Microglial derived tumor necrosis factor-alpha drives Alzheimer's diseaserelated neuronal cell cycle events. Neurobiol Dis. 2014; 62:273-85. https://doi.org/10.1016/j.nbd.2013.10.007.

34. Spilman P, Podlutskaya N, Hart MJ, Debnath J, Gorostiza O, Bredesen D, Richardson A, Strong R, Galvan V. Inhibition of mTOR by rapamycin abolishes cognitive deficits and reduces amyloid-beta levels in a mouse model of Alzheimer's disease. PLoS One. 2010; 5:e9979. https://doi. org/10.1371/journal.pone.0009979.

35. Siman R, Cocca R, Dong Y. The mTOR inhibitor rapamycin mitigates performant pathway neurodegeneration and synapse loss in a mouse model of early-stage-Alzheimertype tauopathy. PLoS One. 2015; 10:e0142340. https://doi. org/10.1371/journal.pone.0142340.

36. Francois A, Rioux Bilan A, Quellard N, Fernandez B, Janet T, Chassaing D, Paccalin M, Terro F, Page G. Longitudinal follow-up of autophagy and inflammation in brain of APPswePS1dE9 transgenic mice. J Neuroinflammation. 2014; 11:139. https://doi.org/10.1186/ s12974-014-0139-x.

37. Xie J, Ponuwei GA, Moore CE, Willars GB, Tee AR, Herbert TP. cAMP inhibits mammalian target of rapamycin complex-1 and -2 (mTORC1 and 2) by promoting complex dissociation and inhibiting mTOR kinase activity. Cell Signal. 2011; 23:1927-35. https://doi.org/10.1016/j. cellsig.2011.06.025.

38. Zheng X, Boyer L, Jin M, Kim Y, Fan W, Bardy C, Berggren T, Evans RM, Gage FH, Hunter T. Alleviation of neuronal energy deficiency by mTOR inhibition as a 
treatment for mitochondria-related neurodegeneration. Elife. 2016; 5. https://doi.org/10.7554/eLife.13378.

39. Barjaktarovic Z, Schmaltz D, Shyla A, Azimzadeh O, Schulz S, Haagen J, Dorr W, Sarioglu H, Schafer A, Atkinson MJ, Zischka H, Tapio S. Radiation-induced signaling results in mitochondrial impairment in mouse heart at 4 weeks after exposure to X-rays. PLoS One. 2011; 6:e27811. https://doi.org/10.1371/journal.pone.0027811.

40. Kempf SJ, Moertl S, Sepe S, von Toerne C, Hauck SM, Atkinson MJ, Mastroberardino PG, Tapio S. Low-dose ionizing radiation rapidly affects mitochondrial and synaptic signaling pathways in murine hippocampus and cortex. J Proteome Res. 2015; 14:2055-64. https://doi.org/10.1021/ acs.jproteome.5b00114.

41. Zhu XH, Qiao H, Du F, Xiong Q, Liu X, Zhang X, Ugurbil K, Chen W. Quantitative imaging of energy expenditure in human brain. Neuroimage. 2012; 60:2107-17. https://doi. org/10.1016/j.neuroimage.2012.02.013.

42. Simpkins JW, Yi KD, Yang SH, Dykens JA. Mitochondrial mechanisms of estrogen neuroprotection. Biochim Biophys Acta. 2010; 1800:1113-20. https://doi.org/10.1016/j. bbagen.2009.11.013.

43. Prajapati P, Sripada L, Singh K, Bhatelia K, Singh R, Singh R. TNF-alpha regulates miRNA targeting mitochondrial complex-I and induces cell death in dopaminergic cells. Biochim Biophys Acta. 2015; 1852:451-61. https://doi.org/10.1016/j.bbadis.2014.11.019.

44. Bernardino L, Agasse F, Silva B, Ferreira R, Grade S, Malva JO. Tumor necrosis factor-alpha modulates survival, proliferation, and neuronal differentiation in neonatal subventricular zone cell cultures. Stem Cells. 2008; 26:2361-71. https://doi.org/10.1634/stemcells.2007-0914.

45. Wen AY, Sakamoto KM, Miller LS. The role of the transcription factor CREB in immune function. $\mathrm{J}$ Immunol. 2010; 185:6413-9. https://doi.org/10.4049/ jimmunol.1001829.

46. Baune BT, Wiede F, Braun A, Golledge J, Arolt V, Koerner H. Cognitive dysfunction in mice deficient for TNF- and its receptors. Am J Med Genet B Neuropsychiatr Genet. 2008; 147b:1056-64. https://doi.org/10.1002/ ajmg.b.30712.

47. Camara ML, Corrigan F, Jaehne EJ, Jawahar MC, Anscomb H, Koerner H, Baune BT. TNF-alpha and its receptors modulate complex behaviours and neurotrophins in transgenic mice. Psychoneuroendocrinology. 2013; 38:3102-14. https://doi. org/10.1016/j.psyneuen.2013.09.010.

48. Marino MW, Dunn A, Grail D, Inglese M, Noguchi Y, Richards E, Jungbluth A, Wada H, Moore M, Williamson B, Basu S, Old LJ. Characterization of tumor necrosis factordeficient mice. Proc Natl Acad Sci USA. 1997; 94:8093-8.

49. Bastos GN, Moriya T, Inui F, Katura T, Nakahata N. Involvement of cyclooxygenase-2 in lipopolysaccharideinduced impairment of the newborn cell survival in the adult mouse dentate gyrus. Neuroscience. 2008; 155:454-62. https://doi.org/10.1016/j.neuroscience.2008.06.020.
50. Ekdahl CT, Claasen JH, Bonde S, Kokaia Z, Lindvall O. Inflammation is detrimental for neurogenesis in adult brain. Proc Natl Acad Sci USA. 2003; 100:13632-7. https://doi. org/10.1073/pnas.2234031100.

51. Monje ML, Toda H, Palmer TD. Inflammatory blockade restores adult hippocampal neurogenesis. Science. 2003; 302:1760-5. https://doi.org/10.1126/science.1088417.

52. Sierra A, Beccari S, Diaz-Aparicio I, Encinas JM, Comeau S, Tremblay ME. Surveillance, phagocytosis, and inflammation: how never-resting microglia influence adult hippocampal neurogenesis. Neural Plast. 2014; 2014:610343. https://doi.org/10.1155/2014/610343.

53. Sparkman NL, Martin LA, Calvert WS, Boehm GW. Effects of intraperitoneal lipopolysaccharide on Morris maze performance in year-old and 2-month-old female C57BL/6J mice. Behav Brain Res. 2005; 159:145-51. https://doi. org/10.1016/j.bbr.2004.10.011.

54. Hefendehl JK, Neher JJ, Suhs RB, Kohsaka S, Skodras A, Jucker M. Homeostatic and injury-induced microglia behavior in the aging brain. Aging Cell. 2014; 13:60-9. https://doi.org/10.1111/acel.12149.

55. Wang L, Hu XH, Huang ZX, Nie Q, Chen ZG, Xiang JW, Qi RL, Yang TH, Xiao Y, Qing WJ, Gigantelli G, Nguyen QD, Li DW. Regulation of CREB functions by phosphorylation and sumoylation in nervous and visual systems. Curr Mol Med. 2016. https://doi.org/CMMEPUB-80552.

56. Sahin M, Saxena A, Joost P, Lewerenz J, Methner A. Induction of $\mathrm{Bcl}-2$ by functional regulation of G-protein coupled receptors protects from oxidative glutamate toxicity by increasing glutathione. Free Radic Res. 2006; 40:1113-23. https://doi.org/10.1080/10715760600838191.

57. Swistowski A, Peng J, Han Y, Swistowska AM, Rao MS, Zeng X. Xeno-free defined conditions for culture of human embryonic stem cells, neural stem cells and dopaminergic neurons derived from them. PLoS One. 2009; 4:e6233. https://doi.org/10.1371/journal.pone.0006233.

58. Kramer OH, Knauer SK, Greiner G, Jandt E, Reichardt S, Guhrs KH, Stauber RH, Bohmer FD, Heinzel T. A phosphorylation-acetylation switch regulates STAT1 signaling. Genes Dev. 2009; 23:223-35. https://doi. org/10.1101/gad.479209.

59. Larsen MR, Thingholm TE, Jensen ON, Roepstorff $P$, Jorgensen TJ. Highly selective enrichment of phosphorylated peptides from peptide mixtures using titanium dioxide microcolumns. Mol Cell Proteomics. 2005; 4:873-86. https://doi.org/10.1074/mcp.T500007-MCP200.

60. McNulty DE, Annan RS. Hydrophilic interaction chromatography reduces the complexity of the phosphoproteome and improves global phosphopeptide isolation and detection. Mol Cell Proteomics. 2008; 7:971-80. https://doi.org/10.1074/mcp.M700543-MCP200.

61. Melo-Braga MN, Ibanez-Vea M, Larsen MR, Kulej K. Comprehensive protocol to simultaneously study protein phosphorylation, acetylation, and N-linked sialylated 
glycosylation. Methods Mol Biol. 2015; 1295:275-92. https://doi.org/10.1007/978-1-4939-2550-6_21.

62. Schwammle V, Leon IR, Jensen ON. Assessment and improvement of statistical tools for comparative proteomics analysis of sparse data sets with few experimental replicates. J Proteome Res. 2013; 12:3874-83. https://doi. org/10.1021/pr400045u.

63. Kempf SJ, Buratovic S, von Toerne C, Moertl S, Stenerlow B, Hauck SM, Atkinson MJ, Eriksson P, Tapio S. Ionising radiation immediately impairs synaptic plasticityassociated cytoskeletal signalling pathways in HT22 cells and in mouse brain: an in vitro/in vivo comparison study. PLoS One. 2014; 9:e110464. https://doi.org/10.1371/ journal.pone.0110464.

64. Vizcaino JA, Deutsch EW, Wang R, Csordas A, Reisinger F, Rios D, Dianes JA, Sun Z, Farrah T, Bandeira N, Binz PA, Xenarios I, Eisenacher M, et al. ProteomeXchange provides globally coordinated proteomics data submission and dissemination. Nat Biotechnol. 2014; 32:223-6. https://doi. org/10.1038/nbt.2839.
65. Pasparakis M, Alexopoulou L, Episkopou V, Kollias G. Immune and inflammatory responses in TNF alpha-deficient mice: a critical requirement for TNF alpha in the formation of primary B cell follicles, follicular dendritic cell networks and germinal centers, and in the maturation of the humoral immune response. J Exp Med. 1996; 184:1397-411.

66. Barnes CA. Memory deficits associated with senescence: a neurophysiological and behavioral study in the rat. J Comp Physiol Psychol. 1979; 93:74-104.

67. Khan AM, Babcock AA, Saeed H, Myhre CL, Kassem M, Finsen B. Telomere dysfunction reduces microglial numbers without fully inducing an aging phenotype. Neurobiol Aging. 2015; 36:2164-75. https://doi.org/10.1016/j. neurobiolaging.2015.03.008. 